ICTD Working Paper 133

Taxing Profits from International Maritime Shipping in Africa: Past, Present and Future of UN Model Article 8 (Alternative B)

Bob Michel and Tatiana Falcão

November 2021 
Taxing Profits from International Maritime Shipping in Africa: Past, Present and Future of UN Model Article 8 (Alternative B) Bob Michel and Tatiana Falcão

ICTD WORKING PAPER 133

First published by the Institute of Development Studies in November 2021

(C) Institute of Development Studies 2021

ISBN: [978-1-78118-886-6]

DOI: $10.19088 /$ ICTD.2021.023

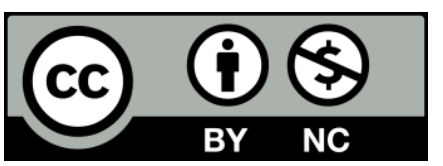

This is an Open Access paper distributed under the terms of the Creative Commons Attribution Non Commercial 4.0 International license, which permits downloading and sharing provided the original authors and source are credited - but the work is not used for commercial purposes. http://creativecommons.org/licenses/by-nc/4.0/legalcode

\section{Available from:}

The International Centre for Tax and Development at the Institute of Development Studies, Brighton BN1 9RE, UK

Tel: +44 (0) 1273606261

Email: info@ictd.ac

Web: www.ictd.ac/publication

Twitter: @ICTDTax

Facebook: www.facebook.com/ICTDtax

IDS is a charitable company limited by guarantee and registered in England

Charity Registration Number 306371

Charitable Company Number 877338 


\title{
Taxing Profits from International Maritime Shipping in Africa: Past, Present and Future of UN Model Article 8 (Alternative B)
}

\author{
Bob Michel and Tatiana Falcão
}

\section{Summary}

International maritime shipping is an essential part of global business. Since the establishment of the current international tax regime in the 1920s, there has been a consensus that profits generated by this business are taxable only in the residence state the state where the shipowners are located. Source states - the port states where business physically takes place - are generally expected to exempt income from international shipping.

This standard is currently reflected in Article 8 of the OECD Model and Article 8 (Alternative A) of the UN Model, and is incorporated in the vast majority of bilateral tax treaties currently in force.

Exclusive residence state taxation of shipping profits is problematic when the size of mercantile fleets and shipping flows between two states are of unequal size. This is often the case in relations between a developed and developing country. The latter often lack a substantial domestic mercantile fleet but serve as an important revenue-generating port state for the fleet of the developed country. To come to a more balanced allocation of taxing rights in such a case, a source taxation alternative has been inserted in UN Model Article 8 (Alternative B). From its inception, Article 8B has been labelled impractical due to the lack of guidance on core issues, like sourcing rules and profit allocation. This gap is said to explain the low adoption rate of Article $8 \mathrm{~B}$ in global tax treaty practice.

In reality, tax treaty practice regarding Article $8 \mathrm{~B}$ is heavily concentrated and flourishing in a handful of countries in South/South-East Asia - Bangladesh, India, Indonesia, Myanmar, Pakistan, the Philippines, Sri Lanka and Thailand. All these countries subject non-resident shipping income to tax in their domestic income tax laws. Except for India, all countries are able to exercise these domestic tax law rules in relation to shipping enterprises located in the biggest shipowner states, either because they have a treaty in place that provides for source taxation or because there is no treaty at all and thus no restriction of domestic law.

None of the relevant tax treaties contain a provision that incorporates the exact wording of Article 8B of the UN Model. If other countries, like coastal countries in sub-Saharan Africa, are looking to implement source taxation of maritime shipping income in the future, they are advised to draw on the South/South-East Asian experience. Best practice can be distilled regarding sourcing rule, source tax limitation, profit attribution and method of taxation (on gross or net basis). In addition to technical guidance on tax, the South/South-East Asian experience also provides important general policy considerations countries should take into account when determining whether source taxation of maritime shipping profits is an appropriate target for their future tax treaty negotiations.

Keywords: international tax; international transport; international shipping; maritime shipping; UN Model; source taxation; OECD Model; tax treaty practice; Article 8 (Alternative B). 
Bob Michel is a policy expert in the field of international tax and development. Bob has provided consultancy services to various international organisations, including UN DESA, CIAT, IATJ and IBFD. He is a frequent author of articles and book contributions on various topics in relation to international taxation.

Tatiana Falcão is a policy expert in international tax and environmental taxation, providing expert consultancy services to the World Bank and African Tax Administration Forum (ATAF). She is the Coordinator for Helsinki Principle 3 (carbon pricing), at the Coalition of Finance Ministers for Climate Action. Tatiana was previously with the UN Environment Programme and UN DESA, overseeing the work of the Committee of Experts in International Cooperation in Tax Matters. 


\section{Contents}

Summary 3

$\begin{array}{ll}\text { Acknowledgements \& Acronyms } & 7\end{array}$

$\begin{array}{lll}1 & \text { Introduction } & 8\end{array}$

2 The international transport business and developing countries 10

$3 \quad$ Taxation of international transport business profits $\quad 11$

$\begin{array}{lll}3.1 & \text { Allocation of taxing rights between states } & 11\end{array}$

3.1.1 Article 8 of the OECD Model: the standard of exclusive
residence state taxation

3.1.2 Exclusive residence state taxation in practice: subsidy race to the bottom and low ETRs 13

3.1.3 Article 8 (Alternative B) of the UN Model: the source taxation alternative 15

3.2 Profit attribution rules for source state taxation 18

3.2.1 Profit attribution rules in tax treaties and domestic law 18

$\begin{array}{ll}\text { 3.2.2 International organisations' (non-)efforts on shipping } & \\ \text { profits attribution rules } & 20\end{array}$

3.3 Availability of information to the source state 24

$4 \quad$ Source taxation of shipping profits in tax treaty practice 25

$\begin{array}{ll}4.1 & \text { Introductory remarks }\end{array}$

4.2 Global survey on source taxation of shipping profits in tax treaties 25

4.3 Individual country survey on source taxation of shipping profits in
tax treaties

$\begin{array}{ll}\text { 4.3.1 Introductory remarks } & 28\end{array}$

$\begin{array}{ll}\text { 4.3.2 Bangladesh } & 28\end{array}$

4.3.3 India 30

4.3.4 Indonesia 32

$\begin{array}{lll}\text { 4.3.5 Myanmar } & 34\end{array}$

4.3.6 Pakistan 35

4.3.7 The Philippines 36

$\begin{array}{lll}\text { 4.3.8 Sri Lanka } & 39\end{array}$

4.3.9 Thailand 40

4.3.10 Summary table 42

5 Conclusion $\quad 44$

5.1 Economic considerations 44

5.2 Tax treaty network and negotiation considerations 47

5.3 Considerations regarding drafting of the treaty provision 50

$\begin{array}{ll}\text { References } & 54\end{array}$

Tables

Table 1 UN Model Article 8 (Alternative B): overview of South/South-East Asian tax treaty practice 43

Table 2 Source taxation in relation to the 10 biggest shipowner nations 44 


\section{Figures}

Figure 1

Countries in South/South-East Asia that have implemented Article 8 (Alternative B) of the UN Model

Figure 2 All bilateral tax treaties signed by countries in sub-Saharan Africa and South/South-East Asia with Article 8 alternatives A and $B$ 


\section{Acknowledgements}

The authors are grateful to Martin Hearson and the anonymous reviewers for their insightful comments on the first draft of this paper. The research and writing of this paper would not have been possible without the support from the International Centre for Tax and Development (ICTD).

\section{Acronyms}

$\begin{array}{ll}\text { CbC } & \text { Country-by-country } \\ \text { CCCTB } & \text { Common Consolidated Corporate Tax Base } \\ \text { COE } & \text { Committee of Experts } \\ \text { ETR } & \text { Effective Tax Rate } \\ \text { GPB } & \text { Gross Philippine Billings } \\ \text { IATA } & \text { International Air Transport Association } \\ \text { ITF } & \text { International Transport Forum } \\ \text { MFN } & \text { Most-favoured nation } \\ \text { MNE } & \text { Multinational enterprise } \\ \text { PE } & \text { Permanent establishment } \\ \text { PoEM } & \text { Place of effective management }\end{array}$




\section{Introduction}

International transport is an essential part of global trade. The international maritime shipping industry was valued at approximately US $\$ 12$ trillion in $2017 .{ }^{1}$ It operates an inherently globalised business with over 60,000 sea vessels, transporting goods and passengers across the world and calling at numerous different ports and countries. ${ }^{2}$ The demand for international shipping of goods is largely determined by developments in the world economy. In volume loaded, maritime trade has increased by a factor of four between 1970 and 2018. Certain segments of the industry are even said to have profited from the COVID-19 crisis, with profits rising as a result of an increase in transport activity during and in the aftermath of the pandemic years (The Economist 2020). ${ }^{3}$

Despite the ever-increasing demand and reasonably steady profits, the shipping industry is a notoriously odd duck in the pond of corporate profit taxation. For decades, the industry has benefited from low effective tax rates on their global profits. Two elements contribute to this outcome.

First, for decades shipping companies have benefitted from beneficial tax regimes. Residence states - the states where the shipping companies are located - have engaged in tax competition to preserve or expand their domestic merchant fleets. This has led to a recurrent reduction in tax rates in residence states, in what can only be referred to as a race to the bottom.

The second element contributing to the low effective tax rate on global profits is the seemingly international consensus that profits from international shipping should only be taxed in the residence state (where these profits are often taxed at low rates), whereas source states - the states between which the transport takes place - should refrain from taxing shipping income.

In a nutshell, when it comes to allocation of taxing rights under a tax treaty, Article 8 of the OECD Model and Article 8 (Alternative A) of the UN Model allocate the right to tax international shipping profits exclusively to the residence state - the place where the enterprise that operates the vessel is located. ${ }^{4}$ This model provision currently figures in a large majority of the bilateral tax treaty network, which accounts for more than 3,500 individual bilateral tax treaties.

The rule of exclusive residence state taxation of international shipping profits might be a stable feature of most bilateral tax treaties, but it is not universally supported. Since the models were developed, developing countries have voiced concern about the unbalanced revenue effects of this rule when a country is an important shipping destination, but does not have a significant domestic shipping business. These concerns led to the inclusion of Article 8 (Alternative B) of the UN Model. Alternative B provides for source state taxation of profits

The value attributed to global seaborne container trade according to Statista, Container Shipping - Statistics \& Facts (2017).

2 International Chamber of Shipping, letter to all full and associate members (ICS(13)44), attachment 2, Treatment of Shipping in the UN Double Taxation Convention Between Developed and Developing Countries - Comments by the International Chamber of Shipping and the World Shipping Council 1 (17 Sept. 2013).

The Economist reports that Maersk, the world's biggest container-shipping firm with $17 \%$ of the market, expects profits of US \$6-7 billion, up from a pre-pandemic estimate of US $\$ 5.5$ billion. Shipping rates for container transport from Asia to the US West Coast have risen by $50 \%$ in the third quarter of 2020 compared to 2019 . The rates for shipping from Asia to West Africa have risen by $18 \%$.

$4 \quad$ The official title of the UN Model is 'United Nations Model Double Taxation Convention between Developed and Developing Countries' (United Nations 2017). 
from international transport by sea, with residual taxing rights for the residence state of the economic operator. Countries electing to employ Alternative B in their tax treaties must therefore agree, using objective allocation criteria, how they will apportion profits between the residence and source state. It is clear that Alternative $B$ was designed specifically to take into account the needs and circumstances of certain coastal low- and middle-income countries that would like to tax shipping activities taking place in their territories.

Despite the above, Alternative $B$ has not found its way into the tax treaty practice of many of those countries, including sub-Saharan countries in Africa. It is illustrative that the 2016 ATAF Model Agreement for the Elimination of Double Taxation with respect to Taxes on Income and the Prevention of Tax Avoidance and Evasion (the ATAF Model), ${ }^{5}$ and its update in 2019, follow the traditional line of exclusive residence state taxation of profits from international transport. The ATAF Model incorporates Article 8 of the OECD Model and Article 8 (Alternative A) of the UN Model, and thereby expressly dismisses the alternative approach suggested in Article 8 (Alternative B) of the UN Model. ${ }^{6}$ The drafters of the ATAF Model do not indicate why they chose to leave Article 8B out of the ATAF Model.

Presumably, the preference for exclusive residence state taxation was included simply because it reflects current tax treaty practice among ATAF member states.

However, different signals are heard from individual ATAF member countries. The ATAF Model's support for exclusive residence state taxation in Article 8(1) has triggered more reservations by member countries than any other provision of the ATAF Model. Ten of the thirty-eight ATAF members (including 8 of the 25 sea-connected countries) have indicated a preference for source taxation of profits from international transport - though, of these ten, only Nigeria has any treaties in force that provide for it. ${ }^{7}$

This contribution aims to assist these countries to answer the following questions:

- Which are the core elements of the international transport business that are of relevance when deciding on the inclusion of Article $8 \mathrm{~B}$ in a tax treaty?

- What is the historical backstory of the apparent consensus on exclusive residence state taxation of shipping profits in Article 8 of the OECD Model, and the seemingly unpopular and underexplored alternative provided in Article 8 (Alternative B) of the UN Model?

- What is actual current treaty practice regarding Article 8 (Alternative B). Are there countries around the globe that have successfully embraced source taxation of shipping profits, and which technical drafting options have they used in their treaties and their domestic tax law?

- Which are the most important policy aspects from an economic perspective in relation to adoption of source taxation of shipping profits?

Starting with a concise description of the international maritime business, the paper then provides an overview of the status and history behind the current consensus that profits

In 2016, the African Tax Administrators Forum (ATAF) released the first edition of the ATAF Model. ATAF's membership includes tax authorities from 38 countries situated in Africa, and the ATAF Model is a regional model that represents a hybrid version of the OECD and UN Models, reflecting the tax treaty policy preferences of the ATAF jurisdictions. The ATAF Model reflects an increased awareness amongst African nations of the importance of a tax treaty policy that is tailored to fit the region's own interests. The ATAF Model (2016) is available at: ATAF Income Tax Model Convention (2016), Treaties and Models, IBFD.

6 See Article 8 of ATAF Income Tax Model Convention (2016) and (2019), Treaties and Models, IBFD, and Article 8 (Alternative B) of the UN Model (United Nations 2017).

7 See ATAF Income Model Convention (2019), Annex - Reservations on Article 8, Treaties and Models, IBFD. The countries reserving the right to tax maritime transport profits at source are: Benin, Gabon, Gambia, Ghana, Kenya, Nigeria, Senegal, Togo and Uganda. The countries reserving the right to tax air transport profits at source are: Benin, Chad, Gabon, Gambia, Ghana, Niger, Nigeria, Swaziland, Togo and Uganda. 
made by international transport companies should be taxed exclusively in the state of residence of the economic operator. The focus then switches to analysing the global tax treaty network with regard to adoption of Alternative B in actual treaty practice. The analysis identifies eight South/South-East Asian countries that have fully embraced source taxation of transport profits in their bilateral tax treaty networks.

The final part of this article presents a set of guidelines for the development of a tax treaty policy to tax international maritime shipping income at source.

The scope of this study is restricted to the allocation of source state taxing rights on profits from maritime shipping. Transport by air is not covered. Article 8 (Alternative B) of the UN Model only applies to international transport by sea. There are nevertheless valid theoretical grounds to argue that air transport profits should be treated along the same lines as maritime shipping profits. In practice, however, even countries that have embraced Article 8 (Alternative B) in their tax treaty policies rarely extend source taxation of transport profits to include transport by air. This is most likely explained by the fact that source taxation of maritime shipping is less likely to give rise to market distortion than air transport. In the Philippines, the only country that has developed a substantial practice of taxing air transport at source, it was this perceived negative impact of source taxation on the country as a flight destination by foreign airlines that made the country decide in 2013 to relinquish its principled stance on source taxation. Significantly, the Philippines continues to levy source taxation on maritime shipping profits. The findings of this study might nevertheless be relevant for future studies of taxation of air transport at source.

\section{The international transport business and developing countries}

International maritime transport covers transport of goods and passengers between two separate countries. International maritime transport of goods is the backbone of globalised trade and the manufacturing supply chain. UNCTAD reports that developing countries account for most global maritime flows, both in terms of exports (goods loaded) and imports (goods unloaded). In 2018, developing countries loaded an estimated 58.8 per cent and unloaded 64.5 per cent of total goods transported by sea. The prominent role of developing countries reflects their ever-growing role as major exporters of raw materials, as well as major exporters and importers of finished and semi-finished products (UNCTAD 2019: sec 1.3:8). In contrast, international maritime transport of passengers is not a sizeable economic activity compared to the transport of goods in most developing countries and most countries in Africa, nor is it expected to be in the future.

As with any other type of business profits, tax on international transport profits is (in the first place) levied by the state where the owner is resident. This may be different to the country in which the vessel is registered. Based on vessel value estimates for 2019, the ten biggest shipowner countries in the world are Greece, Japan, China, Singapore, Norway, US, Germany, South Korea, UK and Denmark. Most of the world's mercantile fleet ownership is in these countries. The share of the mercantile fleet outside Asia, Europe and North America - especially that of Africa - is insignificant, and certainly does not reflect the proportion of these regions in the world's total seaborne trade.

In brief - the business mostly takes place in developing countries, but is almost fully owned and exploited by enterprises located in developed countries. 


\section{Taxation of international transport business profits}

\subsection{Allocation of taxing rights between states}

\subsubsection{Article 8 of the OECD Model: the standard of exclusive residence state taxation}

The main rule on allocation of taxing rights between states on profits from the operation of ships and aircraft in international traffic, currently employed in the vast majority of more than 3,000 bilateral tax treaties currently in force, is modelled after Article 8 of the OECD Model. The Article provides that profits from international traffic are taxable solely in the state were the enterprise operating the ship or aircraft is resident. International traffic is defined in paragraph 3 of the OECD Model as 'any transport by a ship or aircraft except when the ship or aircraft is operated solely between places in a Contracting State and the enterprise that operates the ship or aircraft is not an enterprise of that State'.

To understand why this provision came to be as we know it today, we have to delve into the history of the world's first tax treaty models. Like many rules of international taxation, the current apparent global consensus of exclusive residence state taxation of international shipping profits is ultimately based on an agreement struck by policymakers under the auspices of the League of Nations in the 1920s. In developing the first 'draft bilateral convention for the prevention of double taxation', the technical experts of the League of Nations determined the standard to be exclusive residence state taxation of international shipping profits for two reasons - reciprocity and enforceability.

The experts' conclusion was based on state practice. In the first decades of the $20^{\text {th }}$ century, certain states started adopting reciprocal exemptions for international shipping profits in their domestic laws. Especially for states with a sizeable domestic shipping industry at the time like the US, UK or France - it made sense to exempt (as the source state) profits of foreign shipping companies on the condition that the foreign country granted a similar exemption to its own shipping companies. Article 8 of the OECD Model institutionalised this practice.

Secondly, and more importantly, the technical experts appointed by the League of Nations concluded that with regard to profits realised by international shipping companies, an exception was needed from the permanent establishment (PE) rule. Under the PE rule, business profits are only taxable in the source state if the economic activity in said state meets a certain threshold - for instance, if the taxpayer disposes of a fixed place of business in the source state. When the activities of a shipping company in the source state went beyond its vessels just calling in local ports, the PE threshold is met if the company disposes of facilities to load and unload ships. An exception to the PE rule was however said to be justified based on the following grounds: 'in view of the very particular nature of their activities and of the difficulty of apportioning their profits, particularly in the case of companies operating in a number of countries, the experts admit an exception to this principle' (League of Nations 1925: I(2)(a)).

The resolution by the technical experts - all practical thinkers, appointed national government officials - contrasted sharply with the preceding findings of the 'four economists'. In their seminal 1923 Report on Double Taxation, a report commissioned by the League of Nations to explore the theoretical underpinnings of the allocation of taxing rights on crossborder income, the four economists applied the theory of economic allegiance (League of Nations 1923). The doctrine of economic allegiance served to articulate the ideal allocation of 
taxing rights based on the assessment of four elements - origin, situs, enforceability and domicile -of the taxpayer and their cross-border income. The four economists came to the following conclusions with regard to the economic allegiance of a taxpayer's income from international shipping activities:

1. With regard to the origin of income from ships carrying on international transport activities, they concluded that: 'If the vessels ply the high seas, there is no particular country to which the origin of the yield can be ascribed. If, however, they ply navigable waters which traverse different countries, we have, as in several of the preceding categories, not one, but several, places of origin, [...]. Moreover, in the case of ocean liners there are apt to be in several countries large and extensive docks and appurtenant property which materially contribute to the profitable operation of the vessels.' They added that: 'in as much as the economic yield of vessels depends partly on the seamanship of the captain and to a larger degree upon the business sagacity of the owner, the element of personal management becomes of importance, and that this management may be carried on in the one or the other country. But, as in the case of immovables, the controlling consideration is the existence of the traffic: origin therefore re-enforces domicile (the home of the owner) only to a partial extent'.

2. Likewise, the situs of shipping income could not be ascribed to a single taxable sovereignty.

3. The domicile of the shipowner had a subsidiary importance compared to other factors - it could only reinforce the other factors.

4. In contrast, enforceability was closely related to the country in which the ship was registered (League of Nations 1923: 33).

Finally, the four economists concluded that when a ship traverses different countries, the origin of the income becomes more important than other elements: 'A Dutch flag on a boat plying on the German Rhine should not exempt the vessel from its economic allegiance to Germany'. For ocean liners they concluded that: 'Registry is the chief consideration (because of enforceability considerations), but for purposes of income tax [...] the other country, where expensive docks and shipping offices are found, might reasonably prefer a claim to a part of the earnings' (League of Nations 1923: 33).

Similar opinions were raised in the International Shipping Conference of 1926 . For this reason, the Conference took the view that international shipping profits had to be dealt with in a comprehensive tax treaty so that the one-sided exclusive allocation of taxing rights to the residence state could be balanced by other benefits in favour of the source state. ${ }^{8}$

These are important observations. From a historical perspective, exclusive residence state taxation of shipping profits prevailed, not because of its theoretical underpinnings or its inherent fairness, but because of practical reasons - lack of data in the source state, and lack of workable profit attribution rules.

The rest is history. Source state abdication of taxing rights on shipping profits was endorsed in the first League of Nations Draft Model (1927), and subsequent Mexico Model (1943) and London Model (1946). The OECD Draft (1963) and OECD Model (1977 and subsequent updates) adopted the criterion of exclusive taxation in the state where the place of effective management (PoEM) of the international transport enterprise was established. In the 2014 update of the OECD Model, the PoEM was replaced with the residence criterion, allegedly to 
better reflect current treaty practice of the majority of OECD member countries and nonOECD countries (OECD 2013: para 2).

The OECD's strong support for exclusive residence state taxation of international shipping income was most recently restated in the context of the digital economy debate. In the 2020 Report on the Pillar One Blueprint, the Inclusive Framework on BEPS states that: 'it would be inappropriate to include airline and shipping businesses in the scope of the new taxing right' (i.e. a source state taxing rights on business profits that do not meet the PE threshold). The earnings of international shipping were said to be based on the use of vessels operating in the high seas and multiple tax jurisdictions, and this creates considerable allocation challenges. The report continues that, for this reason, there is a longstanding international consensus that the profits of enterprises operating ships or aircraft in international traffic should be taxable only in the jurisdiction in which the enterprise has its residence, even though these activities would commonly give rise to physical presence in the source state that would give rise to a permanent establishment. Exclusive taxation is however said to remove the compliance and administrative burdens that would otherwise arise, especially over the attribution of profits (OECD 2020a: paras 156-163).

Granted, international shipping activities - a field which by the OECD's own admission involves physical presence in source states - do not fit the description of remote digital activities (activities without physical presence in the source state) currently considered in the Pillar One debate. Yet the Report's reference to profit allocation challenges, and compliance and administrative burdens, in the field of international shipping as justification for the carveout are not convincing and are anachronistic. They are rooted in a 1920s' conception of enforceability. If new nexus and profit attribution rules ought to be devised in the context of the digital economy, it should a fortiori be possible in this age of data and digitalisation to devise such rules for the 'bricks-and-mortar' business of international shipping, without these rules being unenforceable. ${ }^{9}$

As to the 'longstanding international consensus' regarding exclusive residence taxation, the above shows that from the onset of the development of the League of Nations/OEEC/OECD Models, the opinio juris regarding exclusive residence state taxation was not unanimous. It is this dissent that would eventually lead to the development of Article 8 (Alternative B) of the UN Model (see below). As to the 'state practice' that supports this consensus, it is clear that the OECD Model rule is embraced in a vast majority of the more than 3,000 tax treaties currently in force. But the practice is not unanimously endorsed by all countries. We show how a small number of countries have radically abandoned exclusive residence state taxation in nearly all of their tax treaties in section 4.2 .

\subsubsection{Exclusive residence state taxation in practice: subsidy race to the bottom and low ETRs}

One of the consequences of exclusive residence state taxation of international transport - a highly globalised and mobile sector - is that the business was and is exposed, more than any other type of business, to forces of tax competition and to a lower and declining average effective tax rate (ETR), compared to other industries.

It was established above that ownership of the maritime shipping business is concentrated in enterprises located in a handful of states, mostly OECD member states. A 2019 report by the International Transport Forum - an intergovernmental organisation integrated with the OECD - reveals that OECD countries spend at least $€ 3$ billion per year on three maritime subsidies: 
tonnage taxes, tax exemptions for fuel for domestic shipping, and fiscal measures to reduce wage costs of seafarers (ITF 2019: 7). Tonnage tax is the most important (implicit) maritime subsidy. It is a special tax regime for shipping companies under which a notional profit is computed based on the number and size of ships operated, with other corporate income tax rules for depreciation and losses being adjusted. The standard rate of corporate income tax is then applied to the deemed profit, yet the tonnage rate is generally set in such a way that actual tax paid is minimal.

Most major shipowner countries in the world employ a tonnage tax system, mainly for defensive rather than strategic reasons - large and increasing amounts of money are spent on retaining national shipping industries. Subsidies like tonnage tax systems have risen in popularity in reaction to two developments - the use of flags of convenience and open shipping registries, and the use of subsidies in other shipowner countries, thereby effectively creating a so-called race to the bottom. Tonnage tax systems are generally not considered harmful tax practices. The tonnage tax regimes that have been scrutinised by the Inclusive Framework on BEPS Action 5 (Harmful Tax Practices) have generally been deemed compliant with the substantive activity requirement and transparency standard, formulated in the 2015 report (OECD 2015a; OECD 2020b). Further, the tonnage tax systems granted by EU member states are subject to control by the EU Commission when they fall under the legal definition of state aid. To the extent that the countries grant benefits of their respective scheme to all vessels flying the flag of any EU Member State, tonnage tax regimes are usually approved by the EU Commission. ${ }^{10}$

As such, there are two aspects to the international consensus on exclusive residence state taxation. First, there is consensus that source states should in any circumstance refrain from taxing international shipping income. Second, there also seems to be a consensus that residence states are entitled to forego fully exercising their exclusive taxing right by introducing subsidies and preferential regimes, thereby effectively making the international transport business an undertaxed industry.

It has been reported that over the period 2005-2019 maritime transport firms enjoyed an ETR of around 7 per cent. The tax burdens fluctuate per region: the highest rates were observed in Europe (11\%) and Asia (12\%). The lowest burdens were observed in North America (0\%). The cruise shipping business - mostly owned by US companies - is the segment benefitting from an average ETR close to 0 per cent (Merk 2020: 256). Air transport companies also generally benefit from low ETRs. Over the period 2015-2019, US air transport companies paid taxes at an average ETR around 6 per cent. European air transport companies paid taxes at an average ETR around 12 per cent. The average ETR across all sectors in the same period was 21 per cent for US companies, and 23 per cent for European companies (CEPR VOXeu 2020).

The current state of affairs has been questioned in recent years. In a recent report, the OECD's International Transport Forum (ITF) recommends a re-orientation and harmonisation of maritime subsidy policies to stop the race to the bottom, and to make benefits conditional on positive impacts - like the environmental footprint of ships. It further concludes that there is limited evidence that maritime subsidies achieve their stated aims - like defending domestic ship registers and seafarer employment (ITF 2019: 62).

Similar statements have been made by leaders of the industry itself, including claims that shipping subsidies damage the international transport business by artificially increasing liquidity of shipping companies, allowing some of them to renew or expand their fleets. This

10 See, for example, European Commission (2019). 
contributed to increased overcapacity, which put pressure on global shipping rates - making it difficult to generate stable profits or recover from crises.

\subsubsection{Article 8 (Alternative B) of the UN Model: the source taxation alternative}

The arguments voiced but not heard during the development of the League of Nations and OECD Model regarding defending the allocation of taxing rights were eventually taken on board in development of the UN Model.

In its resolution of 4 August 1967, the United Nations Economic and Social Council expressed its belief that 'tax treaties between developed and developing countries can serve to promote the flow of investment useful to the economic development in the latter, especially if the treaties provide for favourable tax treatment to such investments on the part of the countries of origin'. Pursuant to the resolution the Ad Hoc Group of Experts on Tax Treaties between Developed and Developing Countries (the group of experts) was set up, composed of experts and administrators nominated by governments from developed and developing countries, but acting in a personal capacity (United Nations 1969: paras 1-3).

In their First Report (1969), the group of experts highlight that several members from developed countries supported the position taken in Article 8 of the OECD Model. Several members from developing countries were not in favour of exclusive residence state taxation, which would de facto imply that they would not derive any tax revenue from international shipping. They asserted that their countries were not in a position to forgo even limited revenue from taxing foreign shipping enterprises while their own shipping industries were not more fully developed. It was recognised that there were considerable difficulties in determining a taxable profit in this situation. Various methods were proposed, one proposal being the source country to agree to a 50 per cent reduction of tax levied on foreign shipping profits. Issues like the impact of accelerated depreciation, tax deductions and government subsidies in the residence state on tax levied in the source state, were discussed (United Nations 1969: paras 65-68).

In the Third Report (1972), the positions of the developed and developing countries were once more laid out, with the former restating the OECD point of view, and the latter reiterating that, from the standpoint of developing countries, the mutual exemption of shipping profits in the source state appeared to represent a somewhat outdated approach. The problem should not be looked at from the point of a special interest group or of traditional methods, but should be resolved in a manner that would give due consideration to the needs of developing countries (United Nations 1972: paras 13-15). The Members from a number of those countries added that Article 8 of the OECD Model was actually a deterrent for developing countries to sign tax treaties, as it worked exclusively in favour of developed countries. As the four economists had warned in 1923 (see section 3.1.1), it was said that consideration had to be given to the very substantial expenditure that developing countries incurred in the construction of airports and harbour facilities. The developing country experts therefore conclude that: 'it would appear more reasonable to place the geographical source of profits from international transportation at the place where passengers or freight were booked. Considering those problems, an apportionment of shipping profits on the basis of turnover would appear to provide a fair solution' (United Nations 1972: para 16).

Two different problem areas were identified - determination of shipping profits, and allocation of these profits to the various countries concerned. With respect to allocation of profits, suggestions were made both for a formula-based approach and for a unilateral attribution of profits similar to the attribution of profits to a PE. Several experts from both developed and developing countries were in favour of a formula-based approach, because it would prevent 
double (or multiple) taxation of profits (United Nations 1972: para 21). Most members agreed that the adoption of a formula under which net profit, as determined by the residence country, would be multiplied by the ratio of gross receipts from outgoing freight originating in the country to gross receipts on a global basis (United Nations 1972: para 23). A member from a developed country observed that the question remained regarding the portion of income that should be allocated to the home country of the enterprise: 'a shipping enterprise domiciled in a particular country might well conduct all its activities outside that country, with the result that nothing would be left for the latter to tax, although it contributed capital and management to the enterprise' (United Nations 1972: para 26). Developing country members pointed out that an overall net profit figure computed under the rule of the home country might not always be acceptable in source countries, especially where the home country provided special depreciation, investment allowances or other benefits (United Nations 1972: para 27).

The technical experts also discussed the source rule used for income to be allocated to a source country. It was believed that source countries should be able to tax shipping income if two conditions were fulfilled: (i) there was a permanent activity of some kind, such as a PE or a permanent representative, as distinguished from merely occasional contacts in the source country; and (ii) there was a sufficient intensity of connection between the enterprise and the source country (United Nations 1972: para 29). 'A ship might visit a country repeatedly or it might call only once. But if the single call was a planned operation, the profits from the voyage should be taxable' (United Nations 1972: para 32).

The attribution of profits to the source state would occur as follows. The source state would be entitled to tax from outbound transport income - income from freight leaving its territory. In no circumstance should these profits exceed the proportion of worldwide profit that was attributable to the source country.

The experts noted that a shipping enterprise that considered itself too heavily taxed under this method would be free to invoke competent authority procedures under the tax treaties. Special rules were to be devised to prevent shipping enterprise being taxed more excessively in source countries than ordinary business enterprises were under the PE rule (United Nations 1972: para 29-30).

With regard to tax levied in the source state, it was observed that certain developing countries had reduced their tax on shipping profits to one-half under tax treaties. It was believed that 'through such a concession, the cost of capital and management services provided by the home country was recognised' (United Nations 1972: para 33). Albeit not reflected in the text of the Model provision, it was generally agreed that if source country tax was allowed, the focus should be on taxing outgoing freight, not inbound freight. If both were taxed in the source state, it might be advisable to have a different rate of reduction of domestic tax in that state - a lower deduction for outbound transport and a higher deduction for inbound transport. These nuances are not taken on board in the text of the Model provision (and the Commentary), which simply provides that the tax in the source state is to be reduced by a percentage to be established through bilateral negotiations.

The technical experts discussed a report from a special advisor who suggested that two approaches should be considered. One approach would be exclusive residence state taxation, endorsed in the OECD Model. If that rule were to be abandoned, the question arose whether the taxation of shipping income should be governed by the PE rule, or whether specific rules for the shipping industry were necessary (United Nations 1972: para 39).

The work of the Ad Hoc Group of Experts would eventually culminate in the adoption in 1979 of the Manual for the Negotiation of Bilateral Tax Treaties between Developed and 
Developing Countries (United Nations 1979). The Manual presents a set of guidelines based on the technical experts' discussions on issues arising in connection with the negotiation of tax treaties between developed and developing countries (United Nations 1979: 5). Guideline 8A duplicated the text of Article 8 of the OECD Model (1977). Guideline 8B provides for the text which would come to known as Article 8 (Alternative B) of the UN Model (1980), and the observations expressed by the experts in the Manual were incorporated in the Commentary on Article 8 (Alternative B) of the UN Model (1980). Both model provision and commentary have remained unaltered since then.

Paragraphs 1 and 2 of Article 8 Alternative B of the UN Model (2017) read:

1. Profits of an enterprise of a Contracting State from the operation of aircraft in international traffic shall be taxable only in that State.

2. Profits of an enterprise of a Contracting State from the operation of ships in international traffic shall be taxable only in that State unless the shipping activities arising from such operation in the other Contracting State are more than casual. If such activities are more than casual, such profits may be taxed in that other State. The profits to be taxed in that other State shall be determined on the basis of an appropriate allocation of the overall net profits derived by the enterprise from its shipping operations. The tax computed in accordance with such allocation shall then be reduced by is to be established through bilateral negotiations.) per cent. (The percentage

The most relevant observations in the Commentary are the following:

- Article 8 (Alternative A)/Article 8 of the OECD Model is predicated, inter alea, on the premise that exemption in the source states ensures that enterprises will not be taxed in foreign countries if their overall operations turn out to be unprofitable. ${ }^{11}$

- Article 8 (Alternative B) was inspired by certain countries asserting that they were not able to forgo even the limited revenue to be derived from taxing foreign shipping as long as their own shipping industries were not more fully developed. ${ }^{12}$

- Article 8 (Alternative B) grants source state taxing rights on income from both regular or frequent shipping visits and irregular or isolated visits, provided the latter were planned and not merely fortuitous. 'More than casual' means a scheduled or planned visit of a ship to a particular country to pick up freight or passengers. ${ }^{13}$

- Some countries did not agree on the inclusion of the 'more than casual' threshold in Article 8 (Alternative B), and other countries wished to extend Alternative B to cover profits from international air transport, considering the limited size of their domestic airline industry. ${ }^{14}$

- The determination of the profits taxable in the source state should be based on determination of the overall profits in the state of residence (or PoEM state) of the shipping enterprise, with or without taking into account deductions of special allowances, incentives or subsidies granted in the latter state, and losses. The residence state issues source state taxable profit certificates in this regard. ${ }^{15}$

- The apportionment of profits should preferably be based on the factor of outgoing freight receipts. ${ }^{16}$

\footnotetext{
United Nations (2017), Commentary on Article 8 (Alternatives A and B), para. 9.

United Nations (2017), Commentary on Article 8 (Alternatives A and B), para. 3.

United Nations (2017), Commentary on Article 8 (Alternatives A and B), para. 13.

United Nations (2017), Commentary on Article 8 (Alternatives A and B), para. 6.

United Nations (2017), Commentary on Article 8 (Alternatives A and B), para. 14.

United Nations (2017), Commentary on Article 8 (Alternatives A and B), para. 14.
} 
- The source state accepts a reduction in tax due by application of its domestic tax law on the share of profits allocated to it. The reduction reflects the managerial and capital inputs originating in the country of residence. ${ }^{17}$

Schematically, Article 8 (Alternative B) of the UN Model has the following elements:

\section{Article 8 (Alternative B) of the UN Model (2017):}

1. Income covered

- Profits from the operation of ship in international traffic by a resident enterprise

- Alternatively, also profits from operation of aircraft in international traffic by a resident enterprise

- International traffic defined as any transport, except if operated solely between places in other state

2. Residence state taxing rights

- Residual taxing rights for resident enterprise/enterprise with PoEM in the state

- Provides relief for double taxation (credit or exemption)

3. Source state taxing rights

- Shared taxing rights for income covered from activities that are 'more than casual'.

- Alternatively, shared taxing rights for any covered income

- Sourcing rule: 'income from the operation of international traffic in the source state'

4. Method of taxation (in source state)

- Taxation on gross or on net basis

- Reduction of domestic tax due by an agreed percentage, (possibly distinguishing inbound and outbound transport)

\subsection{Profit attribution rules for source state taxation}

\subsubsection{Profit attribution rules in tax treaties and domestic law}

One of the most frequently heard criticisms of Article 8 (Alternative B) of the UN Model is that the Article is something of a lex imperfecta: the UN Model does not provide for clear guidance on profit attribution rules under Article 8B. Critics will argue that there is no point in agreeing to a source state taxing right on profits derived from international shipping, if no agreement can be struck on how the exact amount of these profits are to be determined.

Indeed, on the issue of profit attribution, Article 8B merely provides that shipping profits taxable in the source state 'shall be determined on the basis of an appropriate allocation of the overall net profits derived by the enterprise from its shipping operations'. ${ }^{18}$ The UN Model Commentary does not provide guidance on what constitutes an appropriate allocation. Countries including 8B-type provisions in their tax treaties are thus presented with two options: either they determine on a bilateral basis what constitutes an appropriate allocation and include attribution rules in the treaty provision, or they, individually, resort to their domestic law rules.

United Nations (2017), Commentary on Article 8 (Alternatives A and B), para. 14.

18 See Article 8 (Alternative B) of the UN Model, para 2, third sentence. Hereafter known as the appropriate net allocation rule. 
In practice, countries opted for the second alternative. The appropriate net allocation rule suggested in the UN Model has been a dead letter to date. Besides the fact that the model provision rule does not bring anything substantial to the table - what is an appropriate allocation? - the rule also expressly furthers net taxation of shipping profits. Most countries that embraced Article 8B in their tax treaty policy prefer to leave open the option of taxing source state shipping profits on a gross basis. Many of the relevant countries do so in their domestic tax law. ${ }^{19}$ For this to happen it would be counterproductive to include the appropriate net allocation rule.

The perceived lacuna in Article 8B is thus filled in by domestic law. Most domestic tax systems do contain rudimentary sourcing and profit attribution rules on the taxation of nonresident shipping profits. In many cases, these domestic tax law rules merely serve as a big stick to entice tax treaty partners to sign a tax treaty. As the signing of a tax treaty usually implies agreeing on exclusive residence state taxation, these domestic tax provisions are rarely applied in practice.

But there are instances in which these domestic law rules on non-resident shipping income attribution do come into play. Besides the obvious (but rare) case of the relevant bilateral tax treaty incorporating an Article 8B provision, many pairs of countries do not have tax treaties in place - because they never signed one or because of tax treaty termination policies. In such cases, countries do tend to exercise their sovereign right to tax non-resident shipping company income that is sourced in their territory. Countries apply the profit attribution rules contained in their domestic law to determine how much income is sourced in their territory.

The US terminating its shipping tax agreement with Hong Kong in 2020 illustrates the relevance of domestic rules. Both the US and Hong Kong are important shipowner nations, and, probably as a consequence, both countries employ a tax treaty policy of exclusive residence state taxation of shipping profits. Solidifying this reciprocal exemption was also the sole purpose of the United States Hong Kong Shipping Tax Agreement (1989). ${ }^{20}$ After termination of the Treaty, both states reverted to applying their domestic law rules on nonresident shipping profits derived from 1 January 2021. These provisions include profit attribution rules.

In the case of the US, Hong Kong shipping companies - like any other foreign shipping company that does not benefit from exemption because their home jurisdiction does not grant equivalent reciprocal exemption to US shipping companies - will derive taxable transportation income from US sources if the income is attributable to transportation which begins and ends in the US. ${ }^{21}$ The US Internal Revenue Code further provides that 50 per cent of US source transportation income is to be taxable either at a rate of 4 per cent on the gross amount of US source transportation income, or, if the foreign transport company: (a) maintains a fixed place of business in the US; and (b) at least 90 per cent of the Hong Kong company's US source transportation income is attributable to regularly scheduled transportation, the income is treated as effectively connected to a US business and subject to the ordinary corporate tax rate of 21 per cent and a branch profit tax of 30 per cent on the net after-tax income.

\footnotetext{
$19 \quad$ See section 4.

20 See Agreement Constituted By Exchange Of Notes Between The Government Of The United States Of America And The Government Of Hong Kong For Double Taxation Relief In Respect Of Income From International Operation Of Ships, signed on 1 August 1989, Treaties and Models, IBFD. The US and Hong Kong do not have a comprehensive bilateral income tax treaty in place.

21 See Section 863(c)(1) and (2) of the US Internal Revenue Code, available at: https://www.law.cornell.edu/uscode/text/26/863.
} 
Hong Kong takes a slightly different approach. Hong Kong operates a territorial corporate tax system that implies, if no reciprocal exemptions apply, both resident and non-resident are subject to tax on those shipping profits that are sourced in Hong Kong. According to the Hong Kong Inland Revenue Ordinance, shipping profits with source in Hong Kong are profits from the carriage of goods or persons aboard a ship at any location within the waters of Hong Kong. The law provides that the annual assessable profits are equal to the company's worldwide net profits from shipping multiplied by the fraction of the gross shipping revenue sourced in Hong Kong, taken on the total of worldwide shipping revenue. ${ }^{22}$ Hong Kong thus incorporated into its domestic tax law what is generally known as the maritime formula (see section 3.2.2). Similar to Article 8B of the UN Model, the Hong Kong Inland Revenue Ordinance contains a safe harbour rule that applies (both in the figurative and literal meaning) if the non-resident shipping company's ship called at any location within the waters of Hong Kong and this call was of a casual nature and further calls at any location in Hong Kong waters were improbable. If this is the case, the tax authorities might deem the enterprise not to be carrying on taxable shipping activities in Hong Kong. ${ }^{23}$

Domestic source rules for non-resident shipping income are a standard feature of most income tax systems around the world, including countries in sub-Saharan Africa. In Nigeria, for instance, the Companies Income Tax Act contains rules that are similar to the ones applicable in Hong Kong, including the maritime formula. The Nigerian Companies Income Tax Act does not contain the casual-nature safe harbour, but it allows to revert to determination of the taxable base based on a fair percentage if the maritime formula cannot be applied satisfactorily. The percentage cannot be less than 2 per cent of the full sum receivable in respect of the carriage of passengers or goods shipped. Given that Nigeria has only sixteen bilateral tax treaties currently in force, seven of which provide for source taxation of shipping income, these domestic rules are far more relevant in Nigerian practice, than they are in countries with vast treaty networks providing for exclusive residence state taxation, like the US or Hong Kong. ${ }^{24}$

\subsubsection{International organisations' (non-)efforts on shipping profits attribution rules}

This profit attribution issue is thus de facto solved by the application of domestic law rules in the source state. A great advantage for the latter is that it can apply the same set of rules across the board to whichever non-resident shipping company calls at its ports. This is not an unusual outcome for profit attribution rules. In the case of PEs or associated enterprises (i.e. transfer pricing), profit attribution rules are also not part of the bilateral treaty bargain.

Contrary to PE profit attribution or transfer pricing, there has not been any effort to steer rules on shipping profit attribution towards international convergence. International shipping companies would obviously benefit from this convergence, given that it drastically facilitates compliance. Source states would also benefit, because convergence would lead to the formulation of best practice, which is easier to enforce because it usually draws on taxpayer feedback.

The fact that the OECD has not developed guidance on this is not surprising, given that source taxation of international shipping profits is not included in the OECD Model. It is less obvious why the United Nations has not taken action. After initial deliberations regarding

\footnotetext{
22 See Section $23 \mathrm{~B}(3)$ and (12) of Cap. 112 of the Hong Kong Inland Revenue Ordinance, available at: https://www.elegislation.gov.hk/hk/cap112?xpid=ID_1438402581828_002.

23 See Section 23B(6) of Cap. 112 of the Hong Kong Inland Revenue Ordinance.

24 For an illustration of recent Nigerian jurisprudence on the attribution of shipping profits to Nigeria derived by a French shipping company, see Nigeria: Tax Appeal Tribunal (Lagos Zone), 3 December 2020, No. AT/LZ/CIT/028/2017 (Delmasa SA v. FIRS), Case Law IBFD.
} 
adoption of Article 8 (Alternative B) in the UN Model (1980), the UN Committee of Experts (CoE) has not yet revisited the outstanding issues regarding Article $8 \mathrm{~B}$, which include the lack of country guidance on appropriate net allocation rules. Besides the fact that the UN $\mathrm{CoE}$ has a tight agenda (which is mostly filled with responding to policy developments at the OECD), and lacks substantial support from a resourceful secretariat to develop its own policies, the reason for omission of the topic might be explained by its contentious nature. Developed country voices are usually well represented in the CoE, as are representatives of the international maritime transport sector. Both have few interests in common with regard to source taxation of shipping profits. Furthermore, many developing countries traditionally represented in the CoE have not embraced Article 8B in their tax treaty policies, and the perceived need to further this topic has not been present. This could, however, change in future CoE meetings. Current membership of the CoE (2021-2025) contains more members who represent countries that have embraced Article 8B in their tax treaty policies than the previous membership (2017-2020). ${ }^{25}$ This makes one believe that the time is ripe to put Article 8 (Alternative B) back on the CoE's agenda.

In addition to intergovernmental tax organisations, tax policy guidance and best practice are often also developed by relevant international professional organisations. In the field of maritime shipping, organisations like the International Maritime Organization (IMO) and the International Chamber of Commerce (ICC) have remained silent on the topic of Article 8B and its practical implementation issues. There is a clear benefit for international shipping business to see international convergence on the profit attribution rules. Arguably, the fear that streamlining these rules will convince more source countries to adopt source taxation is greater than the perceived benefit.

This awkward spread between the need to have rules to employ source taxation in practice, and the principled stance against source taxation, is reflected in work by the International Air Transport Association (IATA) on the matter. Unlike its maritime transport counterparts, IATA does provide guidance to its members and to countries with regard to source taxation of (air transport) shipping profits. In its Guidelines for Taxation of International Air Transport Profits, IATA strongly recommends that countries grant reciprocal exemption of tax on international shipping income derived by non-residents, yet at the same time it concedes that some states are simply not willing to adopt the principle of reciprocal exemption of international transport earnings. IATA sets out a number of guidelines for calculation of the net income base in general, dealing with losses, and certain air transport specific concepts like flown revenue and the consequences of interline agreements and code sharing.

Most relevant is IATA's work on income apportionment formulas. In documentation for its member airlines, IATA refers to three generally accepted net income apportionment formulas - the maritime formula, Calcutta formula and Massachusetts formula. IATA reveals that using these income apportionment formulas is a practical solution for profit attribution to source states, both in the air transport and maritime shipping industry, and that use of the formulas is endorsed by countries like Canada, France, Myanmar, South Africa, Afghanistan and Australia (IATA 2018). ${ }^{26}$ In the previous section, it was shown that the maritime formula has

25 The CoE usually has 25 members. The $2017-2020 \mathrm{CoE}$ membership had 4 representatives from countries that had adopted 8B to some extent in their tax treaties (Nigeria, India, Vietnam and Thailand). The 2021-2025 CoE membership has 5 representatives of $8 \mathrm{~B}$ countries (Pakistan, India, Nigeria, Indonesia, and Myanmar). It should be noted that, while nominated by their governments, Committee members serve in their personal capacity. See United Nations, 'UN Tax Committee - 25 members appointed', Secretary-General, 21 July 2021, available at: https://www.un.org/sg/en/content/sg/personnel-appointments/2021-07-21/un-tax-committee-25-members-appointed. 
been incorporated into domestic tax law provisions in Hong Kong and Nigeria to determine tax due on non-resident shipping profits.

Only the maritime formula seems to have been tested by countries in relation to maritime shipping profits. This does not mean that the other two formulas do not represent a valid approach to profit attribution in the maritime shipping sector.

\section{Maritime formula}

The maritime formula is a single factor formula that has historically been used in the maritime shipping industry to measure source state income. It employs sales revenue as the basis for apportioning global net air transportation profit or loss of international enterprises.

- 'Revenue derived from Country X' means gross revenue having its source in Country X;

- 'Global revenue' means the total of international transport revenue appearing in the enterprise's annual profit and loss accounts;

- 'Global net transport profit or loss' means the profit or loss from operation of the international transport business, before income tax, as appearing in the enterprise's annual profit and loss accounts.

\section{Maritime formula}
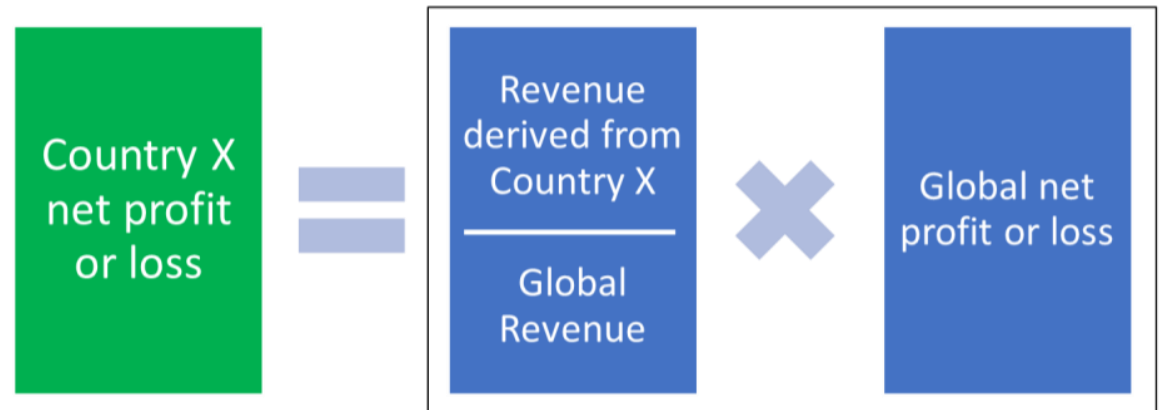

Administration, PS LA 2008/2 (GA), available at:

https://www.ato.gov.au/law/view/document?docid=PSR/GA20082/NAT/ATO/00001 (last accessed: 1 January 2021. 


\section{Calcutta formula}

Under the Calcutta formula, a profit and loss statement is prepared in which all expenses incurred to derive revenue in Country $X$ are deducted from that revenue.

\section{Calcutta formula}
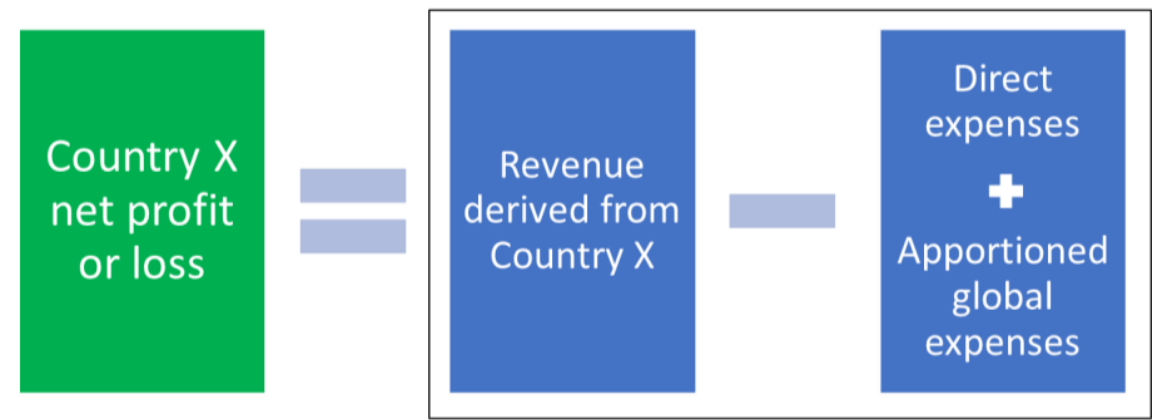

- 'Revenue derived from country $X$ ' is identical to the parameter used in the 'maritime formula' and refers to the gross revenue having its source in Country $X$;

- 'Direct operating expenses in or related to Country $X$ ' include all local costs, passenger services, local administrative costs, local distribution costs, advertisement costs etc.;

- 'Apportioned system expenses' are all expenses other than direct operating expenses incurred in other countries. This item is apportioned according to the ratio of Country X' revenue to the global revenue.

\section{Massachusetts formula}

The Massachusetts formula has its origins in apportionment of income between individual states in the US for the purpose of levying US state tax, and was also used in the EU Commission proposals for a Common Consolidated Corporate Tax Base (CCCTB) for the attribution of multinational enterprise (MNE) profits between EU member states (European Commission 2016). It is a three-factor formula based on property, payroll and sales, giving

\section{Massachusetts formula}

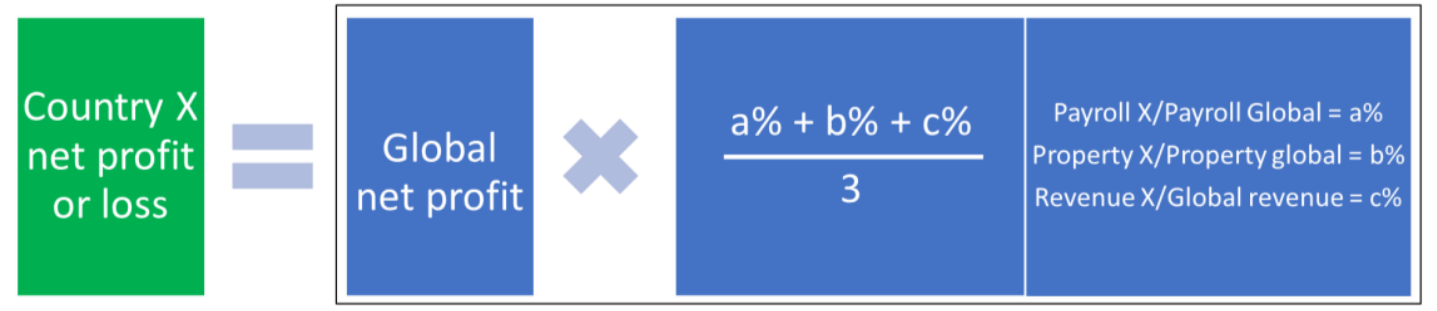

weight to the dominant economic factors contributing to the enterprise's net result.

As may be gathered from the above formulas and examples, attributing shipping profits to a source state would not require rethinking the tax system, or a complex apportionment exercise like the one currently being debated for new taxing rights on digital services provided in a source state. IATA, the agency responsible for regulating air transport activities, has already gone through an exercise of considering apportionment formulas, gathering political support for the use of such formulas and employing them in practical terms. IATA's 
focus is on transport by air. Given the lack of support for source taxation in the maritime sector, it would now be up to the United Nations Tax Committee of Experts to borrow from IATA's work and analyse which of the formulas is most suited to fill in the blanks left in Article 8 (Alternative B), which merely refers to 'an appropriate allocation of the over-all net profits'.

\subsection{Availability of information to the source state}

Another point of criticism often raised, both to reject source taxation of international shipping profits and to justify exclusive residence state taxation, is the fact that information needed for the source state to exercise its taxing right is simply unobtainable. If made obtainable by law, this requirement would be overly burdensome on multinationals engaged in international transport (Falcão 2020a: 1065; 2019).

In the current 'age of data', any argument regarding the impracticality of obtaining data has lost much of its bite. Also, in the field of exchange of information and tax transparency, the world has changed dramatically since the inception of the OECD and UN Models. Recently, under OECD/G20 BEPS Action 13, a minimum standard was developed to require large MNEs to prepare country-by-country $(\mathrm{CbC})$ reports with aggregate data on the global allocation of income, profit, taxes paid and economic activity among tax jurisdictions in which the MNE operates (OECD 2015c). Under the three-tiered CbCR system, MNEs prepare a master file and a $\mathrm{CbC}$ report, both to be submitted in the home country of the MNE, and a local file that is to be filed with the local tax authorities of each country in which the MNE in question is active by means of a constituent entity. A constituent entity is any separate business unit of an MNE that is included in the consolidated financial statements of the MNE Group for financial reporting purposes, and any such business unit that is excluded from the MNE group's consolidated financial statements solely on size or materiality grounds. ${ }^{27}$ In the public consultation preceding the OECD's final report on BEPS Action 13, IATA was keen to point out that, given the standard of exclusive residence taxation, CbCR was not very useful in the case of international transport businesses. The fact that airlines, for instance, pay no or little tax in source countries is due to applicable tax treaties, and not because of any base erosion and profit shifting. Without any PE or associated enterprise activity in these source countries, the purpose of BEPS Action 13 - the provision of data to enforce transfer pricing becomes a moot point (IATA 2013).

This seems to ignore the fact that certain countries have a clear tax treaty practice of preserving source state taxing rights. By its own admission, IATA emphasised that the exercise of these taxing rights should occur on a net income basis (see section 3.2.). The only way to properly determine the amount of net profits is by obtaining data from the transport business' home country, and thus to subscribe to the CbCR regime. The OECD admits as much in its Final Report on BEPS Action 13 on the minimum standard of CbCR. At first sight, it seems that the OECD grants an exemption from $\mathrm{CbCR}$ reporting to the international transport business, even though special industry exemptions are generally deemed inappropriate. The reality is more complex. The Report provides that: "countries participating in the OECD/G20 BEPS Project agree that MNE groups with income derived from international transportation or transportation in inland waterways that is covered by treaty provisions that are specific to such income and under which the taxing rights on such income are allocated exclusively to one jurisdiction, should include the information required by the country-by-country template with respect to such income only against the name of the jurisdiction to which the relevant treaty provisions allocate these taxing rights' (OECD 2015c: para 55). This seems to imply that, in the rare case in which the allocation does not happen

27 OECD (2015c: 31) 'Template for the Country-by-Country Report', http://dx.doi.org/10.1787/9789264241480-en. 
exclusively to one jurisdiction, $\mathrm{CbCR}$ might be deemed necessary for the source state to exercise its sanctioned right to tax international shipping profits.

\section{Source taxation of shipping profits in tax treaty practice}

\subsection{Introductory remarks}

This section surveys the extent to which Article 8 (Alternative B) of the UN Model has been used in global tax treaty practice. In addition to providing an overview of the global incidence of source taxation of shipping profits, the survey also aims to identify any individual countries that have embraced Article 8 (Alternative $B$ ) in their domestic tax treaty policy. The global survey is based on historic findings by other authors on the incidence of Article 8B. Compilation of the findings allows for creation of a time series of incidence.

Next, a closer analysis is made of the relevant treaty provisions of these selected countries to identify model deviations and alterations. To the extent there is available relevant information, the interplay of Article 8B treaty practice and domestic tax law in these countries is analysed, including controversies regarding interpretation and application of the provision by the national courts.

The purpose of the analysis is to draw up guidelines distilled from actual treaty practice that could assist countries contemplating the introduction of source taxation of shipping profits in their own tax treaties, in addition to guidance currently found in the UN Model.

\subsection{Global survey on source taxation of shipping profits in tax treaties}

In 2021, as part of the ICTD Tax Treaties Explorer, Martin Hearson and others compiled data on 2,275 comprehensive bilateral tax treaties concluded before 1 January 2020 by 118 nonOECD countries (Hearson 2021). With regard to the incidence of Article 8 (Alternative B) of the UN Model, the data reveals the following. Out of 1,876 tested tax treaties in force on 1 January 2020, 266 treaties grant taxing rights to source state with regard to profits from international transport by sea and/or air, equalling an incidence of 14 per cent. Prior studies on this topic by Wijnen and others led to similar findings, and also confirmed that Article 8B is very rarely included in tax treaties signed between two OECD countries. ${ }^{28}$

The findings show that the incidence of source taxation of shipping profits in the bilateral tax treaty network is low. Compared to other UN Model provisions that deviate from the OECD Model, Article 8 (Alternative B) is one of the least adopted provisions in treaty practice, even though the provision has been included in the UN Model since its inception. ${ }^{29}$ The numbers

See Wijnen and Magenta (1997: 574-585) and Wijnen and De Goede (2014: 128). The first study covered all comprehensive tax treaties signed between 1 January 1980 - the year in which the UN Model was released - up until 1 April 1997. The global incidence of Article 8 (Alternative B) of the UN Model in the 811 treaties signed in that period was about $13 \%$. The second study covers 1,811 comprehensive tax treaties signed between 1 January 1997 and 1 January 2013. For the treaties signed in this period, the incidence of Article 8 (Alternative B) was about $6 \%$. About half the treaties covered were signed between two OECD countries, and none of the treaties in this group included $8 \mathrm{~B}$. In the group of treaties in which one of the signatory states was a non-OECD country, the inclusion rate was about $12 \%$. The studies also established that of all tax treaties concluded between OECD countries in the whole period from 1970 to 2013 , only three treaties contain a provision similar to Article 8B.

29 For a comparison, see data on the incidence of the other UN Model provisions presented in Wijnen and De Goede (2014: 118-147). 
seem to fuel the common understanding that Article 8B is an anomaly, and not part of what is generally considered sound tax treaty policy for a developing country.

This conclusion is premature. First, Article 8 (Alternative B) of the UN Model is a unique model provision due to its specific scope - it applies to income from sea transport sourced in a country. It only speaks to developing countries with a certain geography - those that have a coastline. Of the 118 developing countries tested in ICTD's Tax Treaties Explorer (2021), 30 were land-locked countries without sea access. ${ }^{30}$ If the total of tested treaties is reduced by the same proportion, the total incidence of Article $8 \mathrm{~B}$ rises to nearly 20 per cent, and closes in on the average level of incidence of other UN Model provisions. The historical analysis does show that the incidence of Article 8 (Alternative B) has remained more or less at a constant level since the inception of the UN Model in 1980. The expansion of the bilateral tax treaty network in the last decades, with developing countries signing more treaties, did not lead to an increased rate of adoption of source taxation on shipping profits in the new treaties.

Secondly, and more importantly, the global survey results do not reflect the concentration of Article $8 \mathrm{~B}$ in the tax treaty practice of individual countries. In other words, the numbers do not indicate whether $8 \mathrm{~B}$ is included in a low number of treaties signed by many different countries, or in a high number of treaties signed by a few countries.

Further analysis of the ICTD dataset reveals that the second hypothesis is true: the concentration of Article 8B is extremely high in a few countries. Of the 118 non-OECD countries covered in the dataset ( 88 of which are not land-locked), it appears that 8 countries are responsible for about 200 of the 266 treaties concluded by 1 or 2 developing countries that provide for source state taxation of shipping profits. In other words, the incidence of Article $8 \mathrm{~B}$ in the treaties of those eight countries is extremely high, to the extent that it is safe to conclude that source taxation of shipping profits is a standard feature of their tax treaty practice.

The eight countries - all located in South/South East Asia - are (in alphabetical order) Bangladesh, India, Indonesia, Myanmar, Pakistan, the Philippines, Sri Lanka and Thailand. Their tax treaty policy on Article 8B is further explored in the country survey in the next section.

30 Afghanistan; Armenia, Azerbaijan, Bhutan, Bolivia, Botswana, Burkina Faso, Burundi, Central African Republic, Chad, Ethiopia, Kazakhstan, Kyrgyz Republic, Lao PDR, Lesotho, Malawi, Mali, Moldova, Mongolia, Nepal, Niger, Paraguay, Rwanda, South Sudan, Tajikistan, Turkmenistan, Uganda, Uzbekistan, Zambia and Zimbabwe. The complete list of countries covered by ICTD's Tax Treaties Explorer dataset can be consulted at: https://www.treaties.tax/faq/. 
Figure 1 Countries in South/South-East Asia that have implemented Article 8 (Alternative B) of the UN model

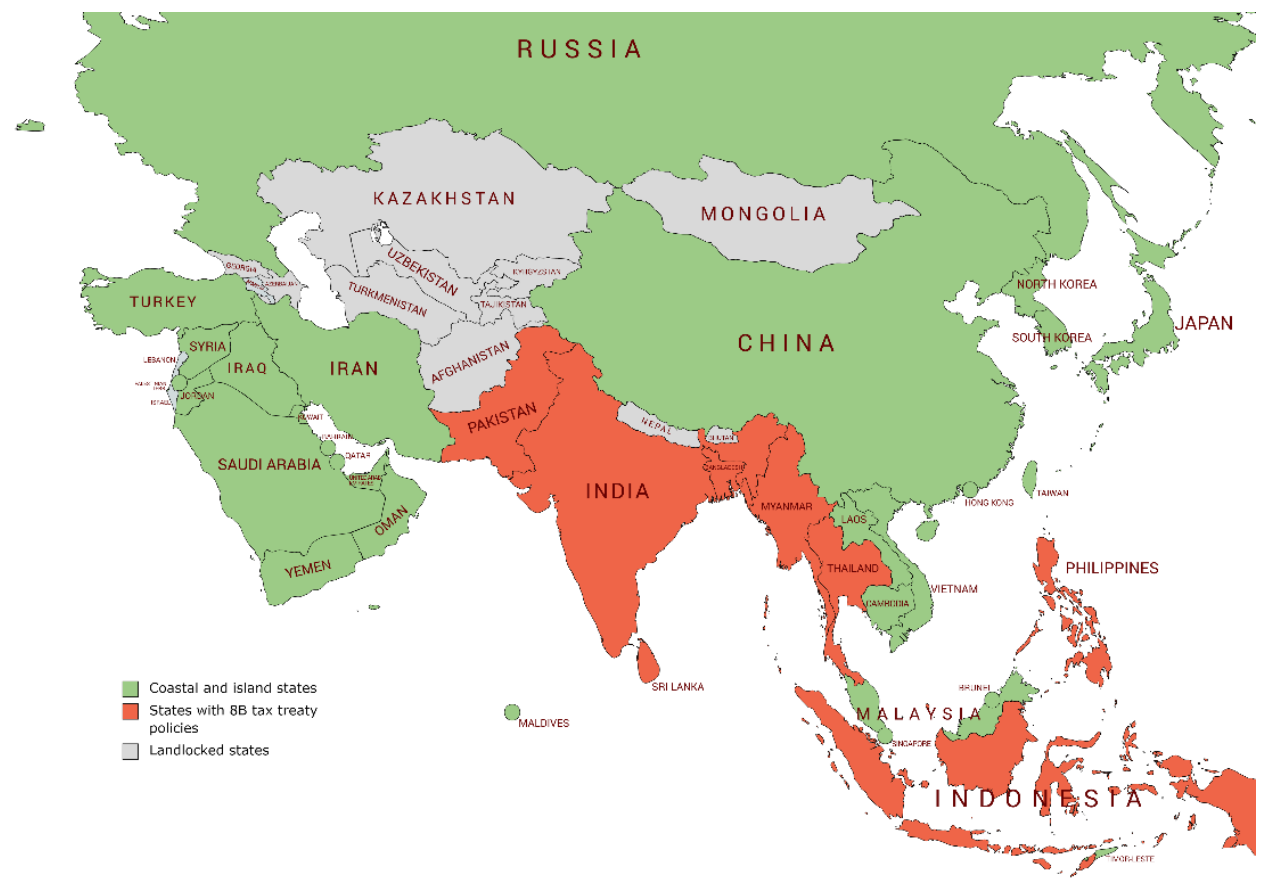

Source: Authors, created using https://mapchart.net/asia.html

Figure 2 All bilateral tax treaties signed by countries in sub-Saharan Africa and South/South East Asia: treaties including Article 8 (Alternative A) in pink and Article 8 (Alternative B) in green.

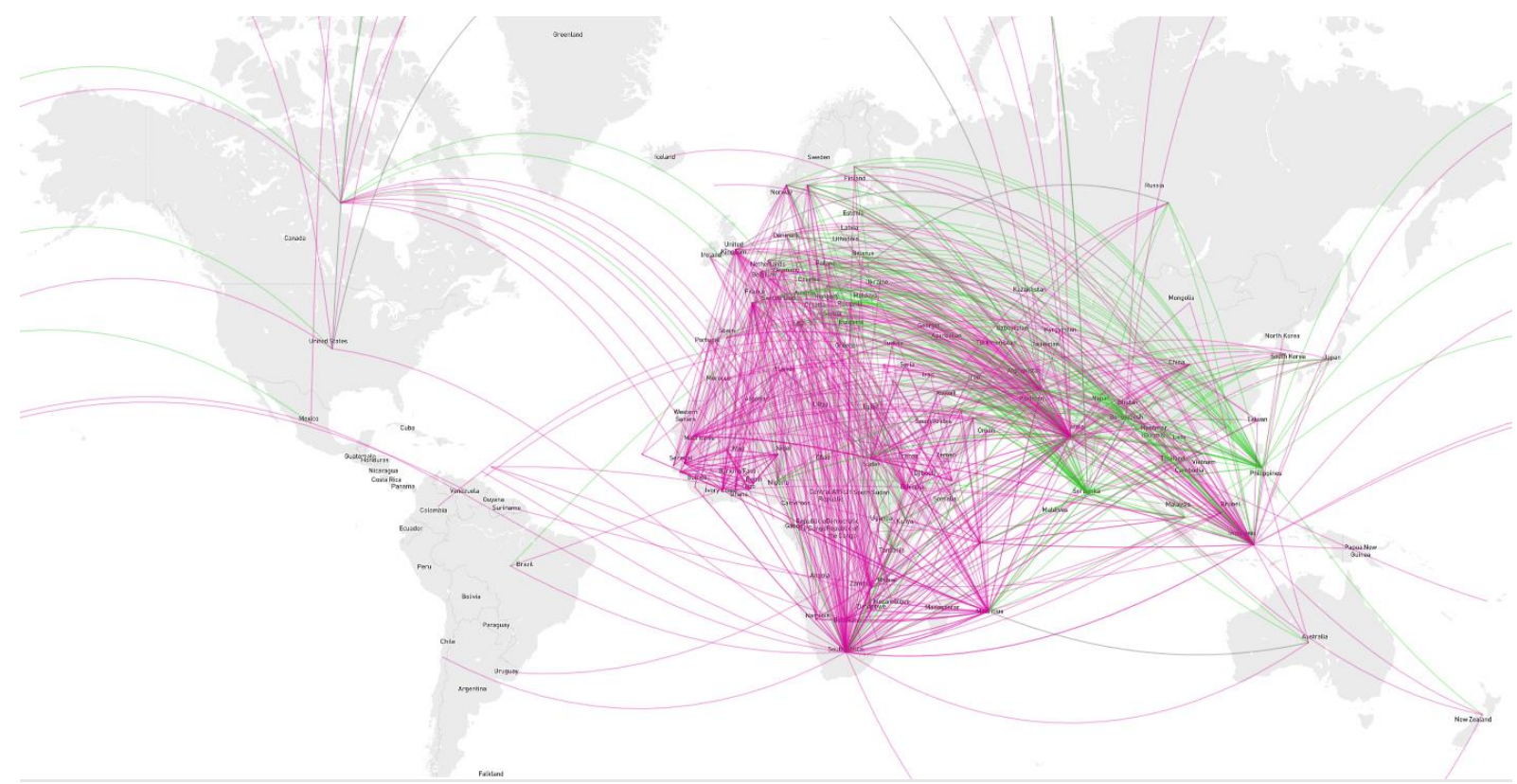

Source: Visualisation by ICTD's Tax Treaties Explorer - www.treaties.tax 


\subsection{Individual country survey on source taxation of shipping profits in tax treaties}

\subsubsection{Introductory remarks}

The following sections provide a country overview of the policies pursued in eight South/South-East Asian countries that have adopted source state taxation of international transport profits in their treaties and domestic tax laws.

A brief overview by country gives the degree of inclusion of Article 8B-type provisions in their tax treaties, and the historical evolution of including source taxation of international transport profits. Because not every treaty state is of economic significance with regard to the size of their mercantile fleet, a review is also provided of the inclusion of source taxation in treaties with the ten biggest ship-owning nations. It is assumed that whether a country is successful in applying its domestic tax laws providing for non-resident shipping income taxation, and effectively taxing the shipping industry doing business in its country, depends largely on whether the country is entitled to tax these profits at source under bilateral treaties with these ten nations.

A brief summary is provided of the principal policy options pursued with regard to the four elements that constitute the taxing right under Article 8 (Alternative B) of the UN Model, as identified in section 3.1.3 - income covered, residence state taxing right, source state taxing right, and method of taxation. This overview provides a picture of the policy employed in countries that have adopted Alternative B of Article 8 as standard treaty policy. The overview is the result of an analysis of relevant provisions in more than 250 bilateral tax treaties signed by these 8 countries that include an Article 8B-type provision.

Given that tax treaties only have a limiting force - they restrict the operation of domestic tax law on cross-border income for the purpose of avoiding double taxation, without creating tax liability - a quick overview is given of domestic tax law with regard to taxation of non-resident income and any relevant controversies settled in domestic jurisprudence with regard to interpretation and application of source state taxing rights on transport profits.

In the last section, a synthesis table provides a clear overview. The purpose of the comparative analysis is to identify policy issues and solutions that need to be anticipated and carefully considered if a country considers implementing a similar policy of taxing transport profits at source in future.

\subsubsection{Bangladesh}

\section{a. General overview of tax treaty network}

Bangladesh currently has 34 comprehensive bilateral tax treaties in force, 31 of which provide for source taxation of international maritime shipping income, including 10 out of 13 treaties signed in the last 20 years. The overall incidence of Article 8B-type provisions in Bangladesh tax treaties is 91 per cent. Of the 34 Bangladesh tax treaties, 17 are signed with OECD countries. Fifteen of these treaties provide for source taxation of maritime shipping income, equaling an incidence of 86 per cent.

Bangladesh is party to one transport tax treaty, signed with Hong Kong in 2000, which provides for exclusive residence state taxation of air transport profits. Maritime shipping is not covered, which implies these profits are taxable in the source state without any restrictions. 
Bangladesh is currently able to enforce source taxation on shipping profits in relation to nine out of the ten biggest ship-owning nations (see Table 2 in Section 4.3.10). Article 8B-type provisions are included in seven treaties: Denmark, Japan, China, US, Norway, Singapore and Korea (Dem. Rep.). The tax treaty with the UK expressly excludes shipping profits from the scope of the treaty, and no treaty is currently in force with Greece. The Bangladesh Germany Tax Treaty (1990) provided for a sunset clause for source state taxation that expired in 2000.

\section{b. Synthesis of tax treaty policy options pursued}

Bangladesh has not succeeded in preserving source state taxing rights on maritime shipping in only two (important) tax treaties - the Bangladesh Germany Tax Treaty (1991) and Bangladesh United States Tax Treaty (2004). The relevant provisions of the other 31 treaties preserving source state taxing rights can be summarised as follows.

- Income covered. The international transport article in all relevant Bangladesh tax treaties allocates source state taxing rights on profits from international maritime transport. No taxing rights are allocated to the source state on profits from air transport.

- Residence state taxing rights. The international transport article in most Bangladesh tax treaties refers to shipping enterprises of a contracting state. A small number of older treaties - all dating from before 2014 - refer to enterprises with their place of effective management (PoEM) in a contracting state.

- Source state taxing rights. Nearly all Bangladesh treaties allocate source state taxing rights with regard to income covered that is 'derived from the other state'. Only a few tax treaties refer to profits from 'where the operation is carried on'. In three treaties - the Bangladesh Philippines Tax treaty (1997), the Bangladesh Canada (1982) Tax Treaty and the Bangladesh United Kingdom Tax Treaty (1979) - maritime transport is not covered in the international transport article and is expressly excluded from the business profits article. Under these treaties, the source state has unlimited taxing rights on these profits, based on a source rule to be determined by domestic law. None of the Bangladesh tax treaties contains an activity threshold ('more than casual' in Article 8B of the UN Model), meaning that the source country can tax any income that meets (domestic law interpretation of) the source rule criteria.

- Method of taxation. All Bangladesh tax treaties provide that the tax charged in the source state shall be reduced by 50 per cent. In a small number of treaties, this tax, after the reduction of 50 per cent, shall not exceed 4 per cent, and in one treaty 2.5 per cent of gross receipts. Apart from treaties with a maximum ceiling of tax calculated on gross receipts, Bangladesh treaties do not determine whether tax in the source state is levied on gross or net profits.

\section{c. Interaction with domestic law}

Under Bangladesh domestic tax law, profits from international transport derived by a nonresident enterprise are taxed on the gross amount. Section 56 of the Bangladesh Income Tax Ordinance (1986) provides that any person responsible for making a payment for air transport or water transport to a non-resident shall, unless such person is himself liable to tax on the amount as an agent in Bangladesh, at the time of making such payment, deduct a tax 
on the amount payable at a rate of 7.5 per cent. ${ }^{31}$ Section $103 \mathrm{~A}$ provides that non-resident operators of aircraft shall be taxable in the aggregate of receipts from the carriage of passengers, livestock, mail or goods loaded at any airport in Bangladesh into the aircraft. This income shall be deemed income from business or profession received in Bangladesh and shall be taxed at the rate of 3 per cent. ${ }^{32}$

\subsubsection{India}

\section{a. General overview of tax treaty network}

India currently has 103 comprehensive bilateral tax treaties in force, 17 of which provide for source taxation of international maritime shipping income, including 6 out of 45 treaties signed in the last 20 years. The overall incidence of Article 8B-type provisions in Indian tax treaties amounts to 17 per cent. Of the 103 Indian tax treaties, 35 are signed with OECD countries. Six of these treaties provide for source taxation of maritime shipping income - an incidence of 17 per cent.

This might look like a relatively low percentage. However, the percentage does not reflect the fact that, from a historical point of view, India has one of the strongest traditions of source taxation of shipping income. Of the bilateral tax treaties signed between India's independence in 1947 and 1980, 90 per cent provided for source taxation. As such, it is not surprising that India is said to have been one of the strong advocates for the insertion of Article 8 (Alternative B) in the UN Model (1980). Of all Indian treaties signed between 1980 and 2000, 40 per cent provided for source taxation. For treaties signed between 2000 and 2020, the inclusion rate dropped to about 16 per cent. ${ }^{33}$ From 1947 to 2013 , India's domestic mercantile fleet is said to have grown by a factor of $55 .{ }^{34}$ This transition from a shipping destination state to a shipowner state might explain India's shift in tax treaty policy. It is unclear whether source taxation helped India to expand its domestic fleet. However, even without evidence of such a causality, it is clear that levying source tax on shipping profits did not prevent the growth of India's domestic fleet, which is an important observation for developing countries contemplating including Alternative B in their tax treaties. The study of India's tax treaties and domestic law remains highly relevant from a tax technical perspective.

India is also party to 14 transport tax treaties. Most of these treaties only deal with airline transport profits, although some also cover maritime shipping profits. In all of these treaties exemption in the source state is granted on the basis of reciprocity, and taxing rights are exclusively allocated to the residence state.

India is currently able to enforce source taxation on shipping profits under its tax treaties with only one of the ten biggest ship-owning nations - Greece (see Table 2 in Section 4.3.10). It has reciprocally agreed to exclusive residence (or PoEM) state taxation in its treaties with China (P.R.C.), Norway, Germany, Korea (Dem. Rep.), Singapore, the UK and the US. Sunset clauses providing source state taxation in treaties with Denmark and Japan have expired.

\footnotetext{
31 Bangladesh: Income Tax Ordinance (1986, as amended in 2015), at section 56, available at: http://nbr.gov.bd/uploads/acts/25.pdf (last accessed: 1 January 2021).

32 Bangladesh: Income Tax Ordinance (1986, as amended in 2015), at section 103A, available at: http://nbr.gov.bd/uploads/acts/25.pdf (last accessed: 1 January 2021).

33 The historic inclusion rates are based on the data compiled and visualised by ICTD's Tax Treaties Explorer (2021), available at: https://www.treaties.tax (last accessed: 15 March 2021).

34 India (2013), Government of India - Ministry of Transport, Indian Shipping Statistics 2013, at p. 7, available at: http://shipmin.gov.in/sites/default/files/ISS\%202013.pdf (last accessed: 15 March 2021).
} 


\section{b. Synthesis of tax treaty policy options pursued}

Relevant provisions of the 17 Indian tax treaties that provide source state taxing rights on international shipping profits can be summarised as follows.

- Income covered. The international transport article in all but one tax treaty allocates source state taxing rights on profits from international maritime transport. The tax treaty with the Philippines allocates source state taxing rights also on profits from air transport.

- Residence state taxing rights. With two exceptions, all relevant tax treaties apply the international transport article to 'resident of a state'. The India Kenya Tax Treaty (2016) is a rare example of a recent treaty using the 'old' rule of place of effective management (PoEM).

- Source state taxing rights. A variety of different source rules are used. A number of treaties apply source state taxing rights to 'profits from the operation within the other state'. A few treaties employ a more restrictive rule and only apply to 'profits from the operation of ships between the ports of the source state and the ports of third countries'. Other treaties do not contain a restrictive sourcing rule or apply to 'profits derived from the other state' or 'profits from sources in the other state'. The India Switzerland Tax Treaty (1994) does not include maritime transport in the transport article, and expressly excludes profits derived thereof from the business profits article. This implies the source state had unlimited taxing rights on said income. A few treaties only grant source state taxing rights to domestic transport in the source state. None of the Indian tax treaties with source state taxing rights currently contains an activity threshold ('more than casual' in Article 8B of the UN Model), meaning that the source country can tax any income that meets (domestic law interpretation of) the source rule criteria. The activity threshold was included in a number of treaties for which a sunset clause (i.e. source state taxation only for the first ten years of application of the treaty) has reverted the treaty back to exclusive residence state taxation.

- Method of taxation. All treaties provide for a reduction of tax in the source state between 40 per cent and 66 per cent, and in most treaties 50 per cent. No limit is provided on the source state taxing rights when they are restricted to domestic transport, or domestic transport between the source state and a third country.

\section{c. Interaction with domestic law}

Under the Indian Income Tax Act (1961), the taxable profit of a non-resident shipping or air transport business is deemed to be a certain percentage of its gross receipts. Section 44B (entitled non-resident shipping business) and section 172 (entitled occasional non-resident shipping business) of the ITA provides that this percentage is 7.5 per cent for international maritime shipping. Section 44BBA determines that this percentage is 5 per cent for international transport by air. Gross receipts are deemed to be the aggregate of any fare or freight paid or payable, whether in India or outside India, for the carriage of passengers, livestock, mail or goods transported from any port or place in India (outbound transport); and any fare or freight received or deemed to be received in India for the carriage of passengers, livestock, mail or goods shipped from any port or place outside India (inbound transport). Gross receipts also include demurrage charge, handling charge or similar payments. ${ }^{35}$ The taxable income is taxed at the rates applicable to foreign companies -40 per cent. The effective tax rate on gross receipts is thus 3 per cent in case of maritime transport and 2 per

35 India: Income Tax Act (1961), as amended by Finance Act (2020), available at:

https://www.incometaxindia.gov.in/pages/acts/income-tax-act.aspx (last accessed: 1 January 2021). 
cent in case of air transport. The non-resident taxpayer is allowed to opt to be taxed under the normal regime. In this case, the tax paid under the system of presumptive taxation is considered an advanced payment of tax.

About 95 per cent of India's foreign trade by volume, and about 70 per cent of its trade by value, currently occurs through international shipping. This has resulted in an abundant body of jurisprudence in which the courts in India consider the scope of the international transport article that mostly provides for exclusive taxation in the residence state (i.e. not India) and other articles (like Article 7 (business profits), Article 12A (fees for technical services) or Article 21 (other income) that grant India taxing rights as the source state. Jurisprudence with regard to the scope of the source state taxing rights under treaties with 8B-type provisions is rare. In a decision rendered in 2004 by the Income Tax Appellate Tribunal (ITAT) of Mumbai, it was held that the transport activities of a Dutch maritime shipping company that owned three ships, one of which had called at ports in India once during the relevant tax year, 1996, and two of which had called at ports in India six times during the year, were more than casual for the purpose of Article 8A(2) of the India Netherlands Tax Treaty. ${ }^{36}$ This Treaty is one of the rare tax treaties with an activity threshold for source state taxing rights, modelled on Article $8 \mathrm{~B}$ of the UN Model. The provision contains a sunset clause, and was only applicable for the first ten years for which the Treaty had effect - until 1998. Currently, air and maritime shipping profits under the India Netherlands Tax Treaty are exclusively taxable in the residence state.

\subsubsection{Indonesia}

\section{a. General overview of tax treaty network}

Indonesia currently has 70 comprehensive bilateral tax treaties in force, 21 of which provide for source taxation of international maritime shipping income, including 10 out of 13 treaties signed in the last 20 years. The overall incidence of Article 8B-type provisions in Indonesian tax treaties amounts to 30 per cent. Of the 70 Indonesian tax treaties, 27 are signed with OECD countries. Five of these treaties provide for source taxation of maritime shipping income, equalling an incidence of 19 per cent.

Indonesia is currently able to enforce source taxation on shipping profits under its tax treaty with only two out of the ten biggest ship-owning nations (see Table 2 in Section 4.3.10) China and Singapore. No treaty has been signed with Greece. Source taxation is excluded in the treaties with Denmark, Germany, Japan, Korea (Dem. Rep.) Norway, the UK and the US.

\section{b. Synthesis of policy options pursued.}

The relevant provisions of the 21 Indonesian tax treaties that provide source state taxing rights on international shipping profits can be summarised as follows.

- Income covered. The international transport article in all relevant Indonesian tax treaties allocates source state taxing rights on profits from international maritime transport. In four tax treaties currently in force, source state taxing rights are also allocated for air transport. In a small number of treaties, the source state taxing rights only cover domestic transport activities.

\footnotetext{
36 India: Income Tax Appellate Tribunal (ITAT) Mumbai, 28 May 2004, James Mackintosh \& Co. (P.) Ltd. V ACIT, Tax Treaty Case Law IBFD.
} 
- Residence state taxing rights. With one exception, all relevant tax treaties apply the international transport article to 'resident of a state'. The Indonesia India Tax Treaty (2012) refers to place of effective management (PoEM).

- Source state taxing rights. A small majority of Indonesian tax treaties allocate source state taxing rights with regard to income 'from sources within the other state'. A few tax treaties do not contain a source rule, and a small number of treaties contain a more specific rule that only catches income from the place 'where the transport operation is carried on'. None of the Indonesian tax treaties contains an activity threshold ('more than casual' in Article 8B of the UN Model), meaning that the source country can tax any income that meets (domestic law interpretation of) the source rule criteria.

- Method of taxation. Nearly all Indonesian tax treaties provide that the tax charged in the source state shall be reduced by 50 per cent. In a small number of treaties, and mostly those restricting the source state taxing rights to domestic transport, there is no limit. The Indonesia Qatar Tax Treaty (2006) is an example of a recent treaty that goes all out, with source state taxing rights on maritime and air transport income derived from sources in the source state, in which the income can be taxed in said state without any limits.

\section{c. Interaction with domestic law}

Article 15 of Indonesian Income Tax Law (1983) provides that foreign shipping and airline operations, namely the transportation of people or goods from a port in Indonesia to an overseas port, are taxed at a rate of 2.4 per cent on the gross profits. Inbound transport is not subject to tax. The rate is derived by assuming a 6 per cent net profit on the gross turnover that is taxed at the current ordinary corporate tax rate of 25 per cent (i.e. 1.5\%) and adding the branch tax of 20 per cent that is due on the assumed 6 per cent net rate after the levying of the corporate tax of 25 per cent (i.e. $0.9 \%$ ). ${ }^{37}$ Under the deemed profit and final tax regime, all costs and depreciation incurred by the transport companies are ignored. A foreign shipping company providing sea transport to and from ports in Indonesia is required to appoint a local shipping company as a general agent in Indonesia. Non-shipping income generated in Indonesia by non-resident transport companies is subject to the ordinary corporate tax rate of 25 per cent. In such cases, relevant costs not related to vessels are deductible.

Article 26 of the Income Tax Law (1983) provides that resident taxpayers are required to withhold tax at a rate of 20 per cent on payments for the provision of services provided by non-residents. Non-resident transport companies doing business in Indonesia and which are not deemed to have a PE in the form of a representative agent are subject to the 20 per cent withholding tax on gross income instead of the tax levied at the rate of 2.4 per cent.

In the past, the Indonesian tax authorities have usually been quick to confirm the existence of a PE of foreign shipping companies, by looking at the PE provisions in the relevant tax treaties. This is much to the benefit of the foreign providers, given the disparity between the rate of 2.4 per cent compared to 20 per cent in case of the absence of a PE. In recent years, tax authorities have been more reluctant to grant access to the benefits of Article 8 of the relevant tax treaties and the domestic low-rate tax regime. For example, in Zinkpower Batam, a decision by the Indonesian Tax Court issued in 2019, the Court sided with the taxpayer to

\footnotetext{
See Indonesia: Income Tax Law Number 7 (1986), articles 15 and 26, available at: https://www.pajak.go.id/id/pph-pasal15 (last accessed: 1 January 2021), and Indonesia: Minister of Finance Decree, 416/KMK.04/1996, 14 June 1996 available at: https://jdih.kemenkeu.go.id/fulltext/1996/416 KMK.04 1996Kep.htm (last accessed: 1 January 2021); Indonesia: Minister of Finance Decree, 417/KMK.04/1996, 14 June 1996, available at:

https://jdih.kemenkeu.go.id/fullText/1996/417 kmk.04 1996kep.htm (last accessed: 1 January 2021);
} 
confirm that transport by a Singaporean shipping company of zinc products between a zinc processing plant in Indonesia and a customer in Singapore fell within the scope of Article 8(2) of the Indonesia Singapore Tax Treaty (1986), and that the Indonesian tax rate thus had to be reduced by 50 per cent. The Court confirmed however that the services were taxed at 20 per cent (reduced to $10 \%$ ), given the lack of a PE in Indonesia. ${ }^{38}$ In Eastern Navigation and Star Global Shipping, the Tax Court went even further by deciding that the charter payments made to two Singaporean shipping companies for shipping a fully equipped coal transport vessel for transport of coal between Indonesia and Singapore were subject to tax at the beneficial rate on foreign shipping income, even if the existence of a PE had not been confirmed. The Court concluded that the signing of a local agent was a regulatory requirement to do business in Indonesia, but nowhere in the tax treaty had it been confirmed that access to the benefit of Article 8 required fulfillment of the PE threshold. ${ }^{39}$

\subsubsection{Myanmar}

\section{a. General overview of tax treaty network}

Myanmar currently has eight comprehensive bilateral tax treaties in force, all of which provide for source taxation of international maritime shipping income. Its tax treaty with Korea (Dem. Rep.) is the only treaty signed with an OECD country and/or with a country listed in the top ten of biggest ship-owning nations (see Table 2 in Section 4.3.10) that provides for source taxation. Given that Myanmar has no tax treaty in place with any of the nine other big ship-owning nations (or any other country), the country is able to exercise its domestic law, taxing non-resident shipping income without any treaty-induced restrictions.

\section{b. Synthesis of policy options pursued}

The international transport provisions in Myanmar tax treaties can be summarised as follows:

- Income covered. The articles only apply to maritime shipping profits.

- Residence state taxing rights. The international transport articles apply the international maritime transport carried on by a 'resident of a state'.

- Source state taxing rights. Six treaties refer to 'income derived from the other state'. Two treaties refer to 'income from sources within the other state'. None of the relevant tax treaties contains an activity threshold ('more than casual' in Article 8B of the UN Model), meaning that the source country can tax any income that meets (domestic law interpretation of) the source rule criteria.

- Method of taxation. All treaties provide for a 50 per cent reduction of the tax levied in the source state. No indication is provided whether this tax is to be levied on a gross or net basis.

Indonesia: Tax Court, 28 January 2019, No. PUT-080089.13, Zinkpower Batam, Tax Treaty Case Law IBFD.

Indonesia: Tax Court, 2 May 2018, No. PUT-101515.35 and PUT-C / 2013 / PP / M.XVB 2018, Eastern Navigation and Star Global Shipping, Tax Treaty Case Law IBFD. This decision contradicts a prior decision by the Tax Court of 2017 in which the Court had confirmed the tax authorities' requirement of the existence of a PE, see: Indonesia: Tax Court, 28 February 2017, No. PUT-81526 / PP / M.IIIA / 13/2017, AAA Shipping, BBB Floating Dock and BBB Offshore Enterprises, Tax Treaty Case Law IBFD. In a decision rendered in 2014, the Tax Court held that similar chartering fees were subject to a withholding tax of $20 \%$, the general rate for services provided by foreign providers, thereby implicitly confirming that the charter fees were outside the scope of Article 8 and in the scope of Article 21 ('other income' of the Singapore Indonesia Tax Treaty. See: Indonesia, Tax Court, 17 December 2014, No. PUT-58605 / PP / M.VIB / 13/2014, Fortune Ocean and Topniche, Tax Treaty Case Law IBFD. 
- Interaction with domestic law. No information available.

\subsubsection{Pakistan}

a. General overview of tax treaty network

Pakistan currently has 66 comprehensive bilateral tax treaties in force, 28 of which provide for source taxation of international maritime shipping income, including 8 out of 25 treaties signed in the last 20 years. The overall incidence of Article 8B-type provisions in Pakistani tax treaties amounts to 42 per cent. Of the 66 Pakistani tax treaties, 23 are signed with OECD countries. Ten of these treaties provide for source taxation of maritime shipping income, equalling an incidence of 43 per cent.

Pakistan is currently able to enforce source taxation on shipping profits under its tax treaty with six of the ten biggest ship-owning nations (see Table 2 in Section 4.3.10). Article 8Btype provisions are included in the treaties with Denmark, Korea (Dem. Rep.), Singapore, Norway and the US. No treaty has been signed with Greece. Source taxation is excluded in the treaties with China (P.R.C.), Germany, Japan and the UK.

\section{b. Synthesis of tax treaty policy options pursued}

The policy options pursued by Pakistan in its 28 tax treaties providing for source state taxation of international shipping profits can be summarised as follows:

- Income covered. In most Pakistani tax treaties providing source state taxing rights, these are restricted to international maritime transport profits. In about one in three tax treaties, the source state taxing rights cover profits from both maritime and air transport.

- Residence state taxing rights. With the exception of three tax treaties, all relevant tax treaties apply the international transport article to 'resident of a state'.

- Source state taxing rights. The majority of tax treaties apply source state taxing rights to income 'derived from sources within the other state'. Only a few treaties refer to income 'from the operation of international transport in the other state'. A few treaties restrict source state taxing rights to profits from local transport and/or domestic container use. None of the Pakistani tax treaties contain an activity threshold ('more than casual' in Article $8 \mathrm{~B}$ of the UN Model), meaning that the source country can tax any income that meets (domestic law interpretation of) the source rule criteria.

- Method of taxation. Nearly all Pakistani tax treaties provide that the tax charged in the source state shall be reduced by 50 per cent. In a small number of treaties, and mostly those restricting source state taxing rights to domestic transport or domestic container use, there is no limit. Three treaties add to the 50 per cent reduction of tax an alternative maximum threshold of between 1 and 4 per cent of gross receipts, implying taxation on gross basis.

- Interaction with domestic law. Since the 1980s, Pakistan taxes income from international shipping under its domestic tax law. The Pakistani approach is said to have been adopted as a result of similar policy developments in other countries in the region like India, Thailand and the Philippines (Ahmed 2020: 113). Section 7 of the Pakistani Income Tax Ordinance (2001) provides that every non-resident person carrying on the business of operating ships or aircraft as the owner or charterer is subject to tax in Pakistan in respect of: 
a. The gross amount received or receivable (whether in or out of Pakistan) for the carriage of passengers, livestock, mail or goods embarked in Pakistan; and

b. The gross amount received or receivable in Pakistan for the carriage of passengers, livestock, mail or goods embarked outside Pakistan.

The amount of tax due by the non-resident is calculated by applying the applicable rate on the gross amounts received. Division V of the First Schedule of the Income Tax Ordinance (2001) stipulates that the rate on maritime shipping income is 8 per cent of the gross amount received or receivable and 3 per cent in the case of air transport. ${ }^{40}$

In A.P. Moller through Maersk Pakistan, a case decided by the Supreme Court of Pakistan in 2012, the highest court confirmed that the Pakistan Denmark Tax Treaty - which allows the source state to tax international maritime shipping profits derived from sources within - does not prevent Pakistan, as the source state, to tax receipts for both inbound and outbound transport. In casu, it was confirmed that the freight receipts by the Danish enterprise for cargo transported to Pakistan on 'free on board' (FOB) basis, paid in Pakistan by the resident buyers of the goods, had their source in Pakistan for the purpose of the treaty and domestic law and were thus subject to tax in Pakistan. ${ }^{41}$

\subsubsection{The Philippines}

\section{a. General overview of tax treaty network}

The Philippines currently has 43 comprehensive bilateral tax treaties in force, all of which provide for source taxation of international maritime and air shipping income, including all 14 treaties signed in the last 20 years. The overall incidence of Article 8B-type provisions in Philippine tax treaties amounts to 100 per cent. Of the 43 Philippine tax treaties, 25 are signed with OECD countries. All these treaties provide for source taxation of maritime and air shipping income.

The Philippines is currently able to enforce source taxation on shipping profits in relation to all the 10 biggest ship-owning nations (see Table 2 in Section 4.3.10). Article 8B-type provisions are included in the treaties with China (P.R.C.), Germany, Denmark, Japan, Korea (Dem. Rep.), Norway, Singapore, the UK and the US. No treaty has been signed with Greece.

\section{b. Synthesis of treaty policy options pursued}

Based on an analysis of the provisions providing source state taxation of international shipping income in 43 Philippine tax treaties, the following conclusions can be drawn with regard to the key policy options:

- Income covered. Unlike in Article 8 (Alternative B) of the UN Model, the international transport article in all relevant Philippine tax treaties allocates source state taxing rights both in relation to international maritime transport and air transport.

- Residence state taxing rights. The international transport article in most Philippine tax treaties refers to shipping enterprises of a contracting state. A small number of older

\footnotetext{
40 Pakistan: Income Tax Ordinance (2001), as amended up to 30 June 2020, available at: https://www.fbr.gov.pk/Categ/Income-Tax-Ordinance/326 (last accessed: 1 January 2021).

41 Pakistan: Supreme Court, 24 January 2012, No. 2012 S C M R 557, A.P. MOLLER through Maersk Pakistan, Tax Treaty Case Law IBFD.
} 
treaties - all dating from before 2014 - refer to enterprises with their place of effective management (PoEM) in a contracting state.

- Source state taxing rights. Nearly all Philippine treaties allocate source state taxing rights with regard to income covered that is derived 'from sources within the other state' or profits 'arising in the other state'. A small number of treaties contain a definition of the income covered under the source rule..$^{42} \mathrm{~A}$ small number of treaties do not contain a source rule. Three treaties do not contain an article dedicated to international transport profits. In these treaties the ordinary PE rule applies. None of the Philippine treaties contains an activity threshold ('more than casual' in Article 8B of the UN Model), meaning that the source country can tax any income that meets (domestic law interpretation of) the source rule criteria.

- Method of taxation. Nearly all Philippine treaties provide that tax charged in the source state shall not exceed 1.5 per cent of the gross revenue derived from sources in said country. In a small number of treaties, the absolute cap is replaced by a relative deduction of 40 per cent. All treaties contain a most-favoured nation (MFN) clause providing that the tax levied in the source state (the Philippines or the other state) shall not exceed the lowest rate of Philippine tax that may be imposed on the relevant profits derived by a resident of a third state. At the time of writing, the MFN clause seems not to have been triggered: 1.5 per cent of gross tax, which equals a 40 per cent reduction of the domestic law rate of 2.5 per cent, seems the universal lowest standard in all Philippine treaties currently in force. Unlike for maritime shipping, in a select few older treaties, there is no similar limit on source state taxing rights on international air transport profits.

\section{c. Interaction with domestic law}

The Philippines' tax treaty policy is concomitant with the country's strong tradition in its domestic law of taxing non-resident profits from international transport sourced in the Philippines, both from air and maritime transport.

Under Section 28(A)(3) of the Philippine National Internal Revenue Code of 1997 (NIRC (1997)), foreign international air and ship carriers are subject to a tax of 2.5 per cent on their 'gross Philippine billings' (GPB). For international shipping carriers, GPB is defined as gross revenue, whether for passengers, cargo or mail originating from the Philippines up to the destination, regardless of the place of issue or payment of the passage ticket of freight document. The 2.5 per cent rate applied on gross billings is said to be determined by assuming a 90 per cent ratio of deductions to a carrier's Philippine gross income and the application of the (old) 25 per cent rate of corporate income tax on the assumed 10 per cent of net income. ${ }^{43}$

42 See Philippines Netherlands Tax Treaty (1989), article. 8(3), which stipulates that: 'profits derived from the other State mean profits as determined under its domestic law realised from the carriage of passengers, excess baggage, mail, livestock or goods boarded or loaded in that other State by a shipping enterprise doing business in that State of passage documents sold therein or from uplifts anywhere in the world by an international carrier doing business in that other State of passage documents sold therein, provided that in such cases the mail, livestock or goods originate from that other State. Profits realised from the carriage of passengers, excess baggage, mail, livestock or goods which are brought to that other State solely for transhipments, or for transfer from one aircraft to another or from an aircraft to a ship or from a ship to an aircraft shall not be included. Profits from chartered flights originating from that other State shall be deemed to be derived from that State regardless of the place of sale of the passage documents. For purposes of determining the taxability of profits from chartered flights, the term 'originating from that other State' shall include flights of passengers who stay in that other State for more than 48 hours prior to embarkation'.

43 Prior to the introduction of the $2.5 \%$ rate applied on gross income in 1972, tax was levied on net income from Philippine sources at the ordinary corporate tax rate. This system was abolished due to problems concerning allocation of income and deductions, mostly due to lack of information regarding the carriers' taxable profits in the residence state. The system also entailed high compliance costs. See Amurao (2012: 7). 
In Association of International Shipping Lines and Maersk, a case decided in February 2020, the Philippine Supreme Court confirmed that demurrage fees and detention fees do not form part of GPB that are subject to 2.5 per cent under Section 28. Demurrage fees are compensation paid to the owner of a vessel by the charterer who remained in possession of the vessel after the contractual period normally allowed to load and unload cargo. Detention fees are charged when a container has not been returned by the consignee to the container owner within the allotted time. The Court confirmed that these payments derived by nonresident shipping companies fall under section 28(A)(1) of the NIRC (1997) and, like any ordinary income derived from sources within the Philippines, they are subject to a tax of 30 per cent on net income (or $15 \%$ on gross income). ${ }^{44}$

The Supreme Court's decision does not deal with the issue of qualification of demurrage and detention fees for the purpose of Philippine tax treaties. It is largely undisputed that this income, derived in relation to charter and container rental activities, is income 'from the operation of ships or aircraft in international traffic' for the purpose of the Treaty if the activities are directly connected or ancillary to the shipping activities. ${ }^{45}$ The Philippine tax treaties typically grant the source country taxing rights to tax this income, but without charging a tax that is higher than 1.5 per cent of the gross revenue derived from the source state. It is difficult to envision how this treaty restriction on gross income is to apply on income like demurrage and detention fees, which is subject on a net basis under domestic law.

From a policy perspective, it might be concluded that, instead of inserting an absolute reduction of tax in the source state, it is better to agree on a reduction expressed in a relative amount. For instance, if the 40 per cent reduction of tax would allow income within GPB to be taxed at the rate of 1.5 per cent instead of the domestic rate of 2.5 per cent. The other income within the scope of Article 8 would be taxed at a rate of 18 per cent instead of 30 per cent on net income.

Finally, it should be mentioned that before Revenue Regulation No. 15-2002 was issued in $2002,{ }^{46}$ gross billings by local agents selling tickets in the Philippines for flights operated entirely in third countries by off-line carriers without landing rights in the Philippines was nevertheless considered shipping income from sources within the Philippines and thus subject to the tax on GPB, even if the airline in question never physically embarked passengers in the Philippines. In Air New Zealand, a decision rendered in 2006 with regard to tax year 2000, the Court confirmed that levying the tax was compatible with Article 8 of the relevant tax treaties. ${ }^{47}$ These tax treaties refer to 'profits from sources within a contracting state', and arguably, selling tickets is a source of profits, even if the transport activities take place in other countries. From a policy perspective, this shows that drafting a precise sourcing rule is critical. Source taxation of shipping income should only apply to income from shipping activities taking place in the source state, irrespective of the place where tickets are sold. The place of the activity is the only relevant nexus between source country and the taxable income.

\footnotetext{
$44 \quad$ Philippines: Supreme Court, 15 January 2020, No. 222239, Association of International Shipping Lines Inc. and MaerskFilipinas Inc. $v$ Secretary of Finance, Tax Treaty Case Law IBFD.

45 See Article 8 of the UN Model (2017), para. 10(2)

46 See Philippines: Department of Finance, Revenue Regulations No. 15-2002, 30 May 2002, at Section 3, available at: https://www.bir.gov.ph/images/bir_files/old_files/pdf/2031rr15_02.pdf (last accessed: 1 January 2021).

47 Philippines: Supreme Court, 28 June 2007, No. C.T.A. 6657, Air New Zealand v Commissioner of Internal Revenue, Tax Treaty Case Law IBFD.
} 


\subsubsection{Sri Lanka}

\section{a. General overview of tax treaty network}

Sri Lanka currently has 47 comprehensive bilateral tax treaties in force, 46 of which provide for source taxation of international maritime shipping income, including all 15 treaties signed in the last 20 years. The overall incidence of Article 8B-type provisions in Sri Lankan tax treaties amounts to 98 per cent. Of the 47 Sri Lankan tax treaties, 20 were signed with OECD countries. Nineteen of these treaties provide for source taxation of maritime shipping income, equalling an incidence of 95 per cent.

Sri Lanka is also part of four bilateral transport tax treaties. All these treaties allow for exclusive residence state taxation of air transport income. The Sri Lanka Hong Kong Transport Tax Treaty (2004) stands out because it is the only one of its kind also dealing with maritime shipping profits, and Hong Kong is an important ship-owning nation. Under the Treaty, the source state is entitled to tax maritime profits from the operations in its territory. ${ }^{48}$

Sri Lanka is currently able to enforce source taxation on shipping profits under its tax treaty with nine of the ten biggest ship-owning nations (see Table 2 in Section 4.3.10). Article 8Btype provisions are included in the treaties with China (P.R.C.), Denmark, Germany, Japan, Korea (Dem. Rep.), Norway, Singapore and the US. No treaty has been signed with Greece. Source taxation is excluded in the treaties with the UK.

\section{b. Synthesis of policy options pursued}

The relevant provisions in the 45 Sri Lankan tax treaties that provide source state taxing rights can be summarised as follows:

- Income covered. Except for the treaty with Bangladesh (1986) and Japan (1967), Sri Lankan treaties only provide source state taxing rights to maritime shipping profits.

- Residence state taxing rights. Except for a few older treaties that refer to the PoEM, Sri Lankan treaties apply to international maritime transport carried on by a 'resident of a state'.

- Source state taxing rights. A majority of the treaties provide taxing rights in relation to income 'from the state where the operation is carried on'. In recent treaties, a broader sourcing rule is applied that refers to income 'derived in the other state'. None of the Sri Lankan treaties contains an activity threshold ('more than casual' in Article 8B of the UN Model), meaning that the source country can tax any income that meets (domestic law interpretation of) the source rule criteria.

- Method of taxation. All treaties provide for a 50 per cent reduction of the tax levied in the source state. No indication is provided whether this tax is to be levied on a gross or on a net basis. In a number of older treaties it is provided that, in any case, the tax cannot exceed between 2 and 6 per cent of gross receipts. This implies the envisioned method of taxation is on gross basis.

48 See Sri Lanka Hong Kong Transport Tax Treaty (2004), article 3(2), Treaties and Models, IBFD. 


\section{c. Interaction with domestic law}

Section 73 of the Inland Revenue Act (2017) of Sri Lanka provides that payments received by a person who conducts a relevant transport business in respect of the carriage of passengers who embark or cargo, mail or other moveable tangible assets that are embarked in Sri Lanka, other than as a result of trans-shipment, or the rental of containers and related equipment which are supplementary or incidental to the carriage are deemed to have their source in Sri Lanka. Section 85 provides that if these payments are made by companies and persons carrying out a business to non-resident persons, they are subject to a withholding tax. ${ }^{49}$ The tax is levied at a rate of 2 per cent on the gross receipts. The withholding tax is final, unless the non-resident has a PE in Sri Lanka for the purpose of Sri Lankan domestic tax law. If a PE exists, profits and losses are to be attributed as if the PE was a separate entity from its head office, and taxation of the net profit would occur at the standard rate of 14 per cent. ${ }^{50}$

\subsubsection{Thailand}

\section{a. General overview of tax treaty network}

Thailand currently has 61 comprehensive bilateral tax treaties in force, 58 of which provide for source taxation of international maritime shipping income, including 23 of the 25 tax treaties signed in the last 20 years. The incidence of Article 8B-type provisions in Thai tax treaties amounts to 95 per cent. Of the 61 Thai tax treaties, 29 are signed with OECD countries. Twenty-five of these treaties provide for source taxation of maritime shipping income, equalling an incidence of 86 per cent.

Thailand is currently able to enforce source taxation on shipping profits in relation to all ten biggest ship-owning nations (see Table 2 in Section 4.3.10). Article 8B-type provisions are included in eight treaties (Japan, China, US, Norway, Singapore, Germany and Korea (Dem. Rep.). The tax treaty with the UK expressly excludes shipping profits from the scope of the treaty which implies that source taxation is possible according to the general permanent establishment rule, and no treaty is currently in force with Greece.

\section{b. Synthesis of treaty policy options pursued}

Based on an analysis of the provisions providing source state taxation of international shipping income in 58 Thai tax treaties, the following conclusions can be drawn with regard to the key policy options:

- Income covered. Nearly all Thai treaties with an 8B-type of provision allocate source state taxing rights only on profits from international transport by sea. Air transport profits are exclusively taxable in the residence state. One exception is the Thailand Philippines Tax Treaty (2013), which also applies source taxation to air transport. The most recent Thai tax treaty extends the source state taxing rights to encompass income from international sea, road and rail transport but not air transport.

49 Sri Lanka: Inland Revenue Act., No. 24 of 2017, available at:

http://www.ird.gov.Ik/en/publications/Acts_Income\%20Tax_2017/IR_Act_No._24_2017_E.pdf (last accessed: 1 January 2021).

50 Sri Lanka: Manual of Inland Revenue Act, No. 24 of 2017, at section 12.1.4, available at:

http://www.ird.gov.Ik/en/publications/Acts_Income\%20Tax_2017/Guide\%20to\%20Inland\%20Revenue\%20Act.pdf (last accessed: 1 January 2017). 
- Residence state taxing rights. The international transport article in most Philippine tax treaties refers to shipping enterprises of a contracting state. Only the Thailand France Tax Treaty (1974) employs the PoEM criterion. The most recently signed treaty, the Thailand Cambodia Tax Treaty (2017), uses place of incorporation as the nexus rule.

- Source state taxing rights. Most recent Thai treaties refer to 'income from the operation of international traffic in the other state'. However, a large majority of the treaties do not contain a sourcing rule. Under these treaties, whether or not income is covered by the source state taxing right depends solely on the domestic tax law of the source state, and can, for instance, cover income from transport in the state but also income from local ticket sales of transport taking place solely in third countries. A few older tax treaties provide that the source state is entitled to tax the income, if the transport enterprise meets the PE threshold in the source state..$^{51}$ None of the Thai treaties contains an activity threshold ('more than casual' in Article 8B of the UN Model), meaning that the source country can tax any income that meets (domestic law interpretation of) the source rule criteria.

- Method of taxation. Except for the treaty with the Philippines which also includes the Philippine 1.5 per cent limit on gross shipping income, all Thai treaties stipulate that the tax levied in the source state is to be reduced by 50 per cent.

\section{c. Interaction with domestic law}

Section 66 of the Revenue Code of Thailand stipulates that foreign companies are subject to tax in Thailand on the net profits from the business carried on in Thailand. Section 67 provides that foreign companies carrying on an international transportation business shall be taxed as follows:

1. In the case of carriage of passengers, 3 per cent of tax is due on the fares, fees and other benefits chargeable in Thailand, deducting any expense from such carriage of passengers;

2. In the case of carriage of goods, 3 per cent of tax is due on the freight charges, fees and other benefits, whether chargeable in Thailand or not, before deducting any expense from such carriage of goods.

Section 67 establishes that an international transport company is a company that carries on transport activities of goods or persons between two or more countries. ${ }^{52}$ Section 68 bis provides that foreign companies carrying on an international transportation business are to keep an account of gross income before deduction of expenses regarding passenger fees, freight fees, and other taxable benefits, instead of keeping an ordinary balance sheet with operational profit and loss accounts. ${ }^{53}$

Under Thai domestic law, different source rules are employed for transport of passengers and transport of goods. Transport of goods is taxable at a rate of 3 per cent of gross freight charges for transport to/from Thailand, regardless where the freight charges are collected.

\footnotetext{
51 See, for example, Thailand Germany (1967), article 8(2), Treaties and Models, IBFD.

52 Section 67 of the Revenue Code of Thailand has recently been amended in this regard by the Act of 22 May 2019 , No. 52, available at: https://www.thailandlawonline.com/revenue-code/corporate-income-tax-law-in-the-revenue-code (last accessed: 1 January 2021).

53 Section 66 and 67 of the Revenue Code of Thailand, available at the website of the Thai tax authorities at https://www.rd.go.th/5939.html\#mata67 (last accessed: 1 January 2021) and also at https://www.thailandlawonline.com/revenue-code/corporate-income-tax-law-in-the-revenue-code (last accessed: 1 January 2021).
} 
Transport of persons to/from Thailand is taxable at the same rate, but only on gross ticketing revenue physically collected in Thailand. This difference might also explain the Thai preference of omitting a specific sourcing rule in its tax treaties. In practice, given the lack of source state taxing rights on air transport profits in nearly all treaties, including those with major airline ownership countries, Thailand has to refrain from taxing air transport profits as per its domestic law.

\subsubsection{Summary table}

The findings from analysis of relevant tax treaties and domestic rules on non-resident taxation of international shipping income are summarised in Table 1. 
Table 1 UN Model Article 8 (Alternative B): overview of South/South East Asian tax treaty practice

\begin{tabular}{|c|c|c|c|c|c|c|c|c|}
\hline & $\begin{array}{c}\text { 8B } \\
\text { Treaties/ } \\
\text { Total Tax } \\
\text { Treaties }\end{array}$ & $\begin{array}{l}\text { Treaty: } \\
\text { Income } \\
\text { covered } \\
\text { (SEA/AIR) }\end{array}$ & $\begin{array}{l}\text { Treaty: } \\
\text { Residence } \\
\text { state } \\
\text { (RES/PoEM) }\end{array}$ & $\begin{array}{l}\text { Treaty: } \\
\text { Sourcing rule (most used) }\end{array}$ & $\begin{array}{l}\text { Treaty: } \\
\text { Taxation method } \\
\text { source state }\end{array}$ & $\begin{array}{l}\text { Domestic } \\
\text { law: } \\
\text { Income } \\
\text { covered }\end{array}$ & $\begin{array}{l}\text { Domestic law: } \\
\text { sourcing rule/tax } \\
\text { base }\end{array}$ & $\begin{array}{l}\text { Domestic law: } \\
\text { method of taxation }\end{array}$ \\
\hline BANGLADESH & $\begin{array}{l}31 / 34 \\
(91 \%)\end{array}$ & SEA & RES & $\begin{array}{l}\text { - Profits derived from the } \\
\text { other state }\end{array}$ & $\begin{array}{l}50 \% \text { reduction of tax (on } \\
\text { gross or net income) }\end{array}$ & SEA/AIR & $\begin{array}{l}\text { Payments made } \\
\text { in country to } \\
\text { non-resident }\end{array}$ & $\begin{array}{l}\text { - } 7.5 \% \text { WHT on } \\
\text { gross (SEA) } \\
\text { - } 3 \% \text { WHT on } \\
\text { gross (AIR) }\end{array}$ \\
\hline INDIA & $\begin{array}{c}17 / 103 \\
(17 \%)\end{array}$ & SEA & RES & $\begin{array}{l}\text { Profits from operation } \\
\text { within the other state } \\
\text { Profits from transport } \\
\text { between source state and } \\
\text { third countries } \\
\text { Profits derived from the } \\
\text { other state }\end{array}$ & $\begin{array}{l}\text { - } 40 \text { to } 66 \% \text { reduction of } \\
\text { tax (on gross or net } \\
\text { income) } \\
\text { - No limit in case of } \\
\text { transport between } \\
\text { source state and third } \\
\text { countries }\end{array}$ & SEA/AIR & $\begin{array}{l}\text { Payments, made } \\
\text { in India or } \\
\text { outside, for } \\
\text { outbound } \\
\text { transport; and } \\
\text { - Payments, made } \\
\text { in India, for } \\
\text { inbound } \\
\text { transport }\end{array}$ & $\begin{array}{l}\text { - } 7.5 \% \text { WHT on } \\
\text { gross (SEA) } \\
\text { - } 5 \% \text { WHT on } \\
\text { gross (AIR) }\end{array}$ \\
\hline INDONESIA & $\begin{array}{l}21 / 70 \\
(19 \%)\end{array}$ & SEA & RES & $\begin{array}{l}\text { - Profits from sources in the } \\
\text { other state }\end{array}$ & $\begin{array}{l}\text { - } 50 \% \text { reduction of tax (on } \\
\text { gross or net income) }\end{array}$ & SEA/AIR & $\begin{array}{l}\text { - Gross turnover } \\
\text { on outbound } \\
\text { transport }\end{array}$ & $\begin{array}{l}2.40 \% \text { on gross } \\
\text { (based on } 6 \% \\
\text { deemed net } \\
\text { profits) (SEA and } \\
\text { AIR) } \\
\text { 20\% WHT if no } \\
\text { PE/agent in } \\
\text { source state }\end{array}$ \\
\hline MYANMAR & $\begin{array}{c}8 / 8 \\
(100 \%)\end{array}$ & SEA & RES & $\begin{array}{l}\text { - Profits derived from } \\
\text { (sources in) the other state }\end{array}$ & $\begin{array}{l}\text { - } 50 \% \text { reduction of tax (on } \\
\text { gross or net income) }\end{array}$ & $\begin{array}{c}\text { (no } \\
\text { informat } \\
\text { ion) }\end{array}$ & (no information) & (no information) \\
\hline PAKISTAN & $\begin{array}{l}28 / 66 \\
(43 \%)\end{array}$ & SEA & RES & $\begin{array}{l}\text { - Profits from sources in the } \\
\text { other state }\end{array}$ & $\begin{array}{l}50 \% \text { reduction of tax (on } \\
\text { gross or net income) }\end{array}$ & SEA/AIR & $\begin{array}{l}\text { - Gross payments, } \\
\text { wherever } \\
\text { received, for } \\
\text { outbound } \\
\text { transport; and } \\
\text { - Gross payments } \\
\text { in Pakistan for } \\
\text { inbound } \\
\text { transport }\end{array}$ & $\begin{array}{l}\text { - } 8 \% \text { WHT on } \\
\text { gross (SEA) } \\
\text { - } 3 \% \text { WHT on } \\
\text { gross (AIR) }\end{array}$ \\
\hline PHILIPPINES & $\begin{array}{l}43 / 43 \\
(100 \%)\end{array}$ & SEA/AIR & RES & $\begin{array}{l}\text { - Profits arising in the other } \\
\text { state }\end{array}$ & $\begin{array}{l}\text { - Max. } 1.5 \% \text { on gross } \\
\text { revenue } \\
\text { - MFN clause lowest rate } \\
\text { in Philippine tax treaties }\end{array}$ & SEA/AIR & $\begin{array}{l}\text { 'gross Philippine } \\
\text { billings' (i.e. } \\
\text { gross revenue } \\
\text { derived from } \\
\text { outbound } \\
\text { transport, } \\
\text { wherever paid) }\end{array}$ & $\begin{array}{l}-2.5 \% \text { on gross } \\
\text { receipts (SEA } \\
\text { and AIR) }\end{array}$ \\
\hline SRI LANKA & $\begin{array}{l}46 / 47 \\
(95 \%)\end{array}$ & SEA & RES & $\begin{array}{l}\text { - Profits from the state } \\
\text { where the operation is } \\
\text { carried on } \\
\text { - Profits derived in the other } \\
\text { state }\end{array}$ & $\begin{array}{l}\text { - } 50 \% \text { reduction of } \operatorname{tax} \text { (on } \\
\text { gross or net income) }\end{array}$ & SEA/AIR & $\begin{array}{l}\text { - Payments for } \\
\text { outbound } \\
\text { transport are } \\
\text { deemed to have } \\
\text { source in country }\end{array}$ & $\begin{array}{l}\text { - } 2 \% \text { on gross } \\
\text { receipts (SEA } \\
\text { and AIR) } \\
\text { - If PE in Sri Lanka: } \\
\text { net taxation at } \\
\text { standard rate of } \\
14 \%\end{array}$ \\
\hline THAILAND & $\begin{array}{l}58 / 61 \\
(86 \%)\end{array}$ & SEA & RES & $\begin{array}{l}\text { - Profits from the operation } \\
\text { in the other state } \\
\text { - No sourcing rule } \\
\text { - If PE in source state }\end{array}$ & $\begin{array}{l}\text { - } 50 \% \text { reduction of tax (on } \\
\text { gross or net income) }\end{array}$ & SEA/AIR & $\begin{array}{l}\text { - Goods: Gross } \\
\text { freight charges } \\
\text { inbound and } \\
\text { outbound } \\
\text { transport } \\
\text { - Passengers: gross } \\
\text { ticketing revenue } \\
\text { physically } \\
\text { connected to } \\
\text { Thailand with } \\
\text { deduction of } \\
\text { expenses }\end{array}$ & $\begin{array}{l}\text { Goods: } 3 \% \text { on } \\
\text { gross receipts } \\
\text { - Passengers: } 3 \% \\
\text { on gross } \\
\text { ticketing } \\
\text { receipts after } \\
\text { deduction of } \\
\text { expenses }\end{array}$ \\
\hline
\end{tabular}


Table 2 Source taxation in relation to the 10 biggest shipowner nations

\begin{tabular}{|c|c|c|c|c|c|c|c|c|c|c|}
\hline & GREECE & JAPAN & CHINA & SINGAPORE & NORWAY & $\begin{array}{l}\text { UNITED } \\
\text { STATES }\end{array}$ & GERMANY & $\begin{array}{l}\text { SOUTH } \\
\text { KOREA }\end{array}$ & $\begin{array}{l}\text { UNITED } \\
\text { KINGDOM }\end{array}$ & $\begin{array}{l}\text { DEN } \\
\text { MARK }\end{array}$ \\
\hline BANGLADESH & $\begin{array}{c}\text { Yes } \\
\text { (no treaty) }\end{array}$ & $\begin{array}{c}\text { Yes } \\
\text { (treaty) }\end{array}$ & $\begin{array}{c}\text { Yes } \\
\text { (treaty) }\end{array}$ & $\begin{array}{c}\text { Yes } \\
\text { (treaty) }\end{array}$ & $\begin{array}{c}\text { Yes } \\
\text { (treaty) }\end{array}$ & $\begin{array}{c}\text { Yes } \\
\text { (treaty) }\end{array}$ & $\begin{array}{c}\text { No } \\
\text { (treaty) }\end{array}$ & $\begin{array}{c}\text { Yes } \\
\text { (treaty) }\end{array}$ & $\begin{array}{c}\text { Yes } \\
\text { (treaty) }\end{array}$ & $\begin{array}{c}\text { Yes } \\
\text { (treaty) }\end{array}$ \\
\hline INDIA & $\begin{array}{c}\text { Yes } \\
\text { (treaty) }\end{array}$ & $\begin{array}{c}\text { No } \\
\text { (treaty) }\end{array}$ & $\begin{array}{c}\text { No } \\
\text { (treaty) }\end{array}$ & $\begin{array}{c}\text { No } \\
\text { (treaty) }\end{array}$ & $\begin{array}{c}\text { No } \\
\text { (treaty) }\end{array}$ & $\begin{array}{c}\text { No } \\
\text { (treaty) }\end{array}$ & $\begin{array}{c}\text { No } \\
\text { (treaty) }\end{array}$ & $\begin{array}{c}\text { No } \\
\text { (treaty) }\end{array}$ & $\begin{array}{c}\text { No } \\
\text { (treaty) }\end{array}$ & $\begin{array}{c}\text { No } \\
\text { (treaty) }\end{array}$ \\
\hline INDONESIA & $\begin{array}{c}\text { Yes } \\
\text { (no treaty) }\end{array}$ & $\begin{array}{c}\text { No } \\
\text { (treaty) }\end{array}$ & $\begin{array}{c}\text { Yes } \\
\text { (treaty) }\end{array}$ & $\begin{array}{c}\text { Yes } \\
\text { (treaty) }\end{array}$ & $\begin{array}{c}\text { No } \\
\text { (treaty) }\end{array}$ & $\begin{array}{c}\text { No } \\
\text { (treaty) }\end{array}$ & $\begin{array}{c}\text { No } \\
\text { (treaty) }\end{array}$ & $\begin{array}{c}\text { No } \\
\text { (treaty) }\end{array}$ & $\begin{array}{c}\text { No } \\
\text { (treaty) }\end{array}$ & $\begin{array}{c}\text { No } \\
\text { (treaty) }\end{array}$ \\
\hline MYANMAR & $\begin{array}{c}\text { Yes } \\
\text { (no treaty) }\end{array}$ & $\begin{array}{c}\text { Yes } \\
\text { (no treaty) }\end{array}$ & $\begin{array}{c}\text { Yes } \\
\text { (no treaty) }\end{array}$ & $\begin{array}{c}\text { Yes } \\
\text { (no treaty) }\end{array}$ & $\begin{array}{c}\text { Yes } \\
\text { (no treaty) }\end{array}$ & $\begin{array}{c}\text { Yes } \\
\text { (no treaty) }\end{array}$ & $\begin{array}{c}\text { Yes } \\
\text { (no treaty) }\end{array}$ & $\begin{array}{c}\text { Yes } \\
\text { (treaty) }\end{array}$ & $\begin{array}{c}\text { Yes } \\
\text { (no treaty) }\end{array}$ & $\begin{array}{c}\text { Yes } \\
\text { (no treaty) }\end{array}$ \\
\hline PAKISTAN & $\begin{array}{c}\text { Yes } \\
\text { (no treaty) }\end{array}$ & $\begin{array}{c}\text { No } \\
\text { (treaty) }\end{array}$ & $\begin{array}{c}\text { No } \\
\text { (treaty) }\end{array}$ & $\begin{array}{c}\text { Yes } \\
\text { (treaty) }\end{array}$ & $\begin{array}{c}\text { Yes } \\
\text { (treaty) }\end{array}$ & $\begin{array}{c}\text { Yes } \\
\text { (treaty) }\end{array}$ & $\begin{array}{c}\text { No } \\
\text { (treaty) }\end{array}$ & $\begin{array}{c}\text { Yes } \\
\text { (treaty) }\end{array}$ & $\begin{array}{c}\text { No } \\
\text { (treaty) }\end{array}$ & $\begin{array}{c}\text { Yes } \\
\text { (treaty) }\end{array}$ \\
\hline PHILIPPINES & $\begin{array}{c}\text { Yes } \\
\text { (no treaty) }\end{array}$ & $\begin{array}{c}\text { Yes } \\
\text { (treaty) }\end{array}$ & $\begin{array}{c}\text { Yes } \\
\text { (treaty) }\end{array}$ & $\begin{array}{c}\text { Yes } \\
\text { (treaty) }\end{array}$ & $\begin{array}{c}\text { Yes } \\
\text { (treaty) }\end{array}$ & $\begin{array}{c}\text { Yes } \\
\text { (treaty) }\end{array}$ & $\begin{array}{c}\text { Yes } \\
\text { (treaty) }\end{array}$ & $\begin{array}{c}\text { Yes } \\
\text { (treaty) }\end{array}$ & $\begin{array}{c}\text { Yes } \\
\text { (treaty) }\end{array}$ & $\begin{array}{c}\text { Yes } \\
\text { (treaty) }\end{array}$ \\
\hline SRI LANKA & $\begin{array}{c}\text { Yes } \\
\text { (no treaty) }\end{array}$ & $\begin{array}{c}\text { Yes } \\
\text { (treaty) }\end{array}$ & $\begin{array}{c}\text { Yes } \\
\text { (treaty) }\end{array}$ & $\begin{array}{c}\text { Yes } \\
\text { (treaty) }\end{array}$ & $\begin{array}{c}\text { Yes } \\
\text { (treaty) }\end{array}$ & $\begin{array}{c}\text { Yes } \\
\text { (treaty) }\end{array}$ & $\begin{array}{c}\text { Yes } \\
\text { (treaty) }\end{array}$ & $\begin{array}{c}\text { Yes } \\
\text { (treaty) }\end{array}$ & $\begin{array}{c}\text { No } \\
\text { (treaty) }\end{array}$ & $\begin{array}{c}\text { Yes } \\
\text { (treaty) }\end{array}$ \\
\hline THAILAND & $\begin{array}{c}\text { Yes } \\
\text { (no treaty) }\end{array}$ & $\begin{array}{c}\text { Yes } \\
\text { (treaty) }\end{array}$ & $\begin{array}{c}\text { Yes } \\
\text { (treaty) }\end{array}$ & $\begin{array}{c}\text { Yes } \\
\text { (treaty) }\end{array}$ & $\begin{array}{c}\text { Yes } \\
\text { (treaty) }\end{array}$ & $\begin{array}{c}\text { Yes } \\
\text { (treaty) }\end{array}$ & $\begin{array}{c}\text { Yes } \\
\text { (treaty) }\end{array}$ & $\begin{array}{c}\text { Yes } \\
\text { (treaty) }\end{array}$ & $\begin{array}{c}\text { Yes } \\
\text { (treaty) }\end{array}$ & $\begin{array}{c}\text { Yes } \\
\text { (treaty) }\end{array}$ \\
\hline
\end{tabular}

\section{Conclusion: policy recommendations}

The purpose of this study is to investigate policy considerations that should guide a country's decision to embrace source taxation of international transport profits in its tax treaties and domestic law. The study thereby aims to assist African countries that have shown interest in source taxation by expressing a reservation to Article 8(1) of the ATAF Model (2019), which provides for exclusive residence state taxation of international transport profits.

Three types of objectives should be considered to answer the question whether and to what extent a country should pursue a tax treaty policy in line with Article 8 (Alternative B) of the UN Model: economic considerations (why tax international shipping activities), tax treaty negotiation considerations (how to amend/sign tax treaties with source taxation), and tax technical considerations regarding the drafting of the treaty provision (how to phrase the tax treaty provision).

\subsection{Economic considerations}

\section{Revenue, fleet protection and environmental concerns}

There are a number of reasons for a source country to refuse to relinquish the right in its tax treaties to tax profits from international transport activities from sources in its territory. One of the most obvious reasons is the potential to gather tax revenue. A second reason is to protect or incentivise the development of a local fleet of air and maritime transport providers. A third reason, which is currently untested in treaty practice but will gain relevance in the (near) future, is the potential for the source country to use corporate income tax on shipping activities as a tool to foster environmental protection.

The allure of the first consideration, gathering revenue, is clear. Given that ownership of the shipping business for African countries lays largely with non-resident enterprises, taxing their profits increases revenue without increasing the domestic tax burden. The exact dimensions of revenue generation potential depends on country-specific parameters, like the segments of the transport business active in the country, the frequency of the calls and the volume of goods shipped. 
The second consideration is protection and development of a domestic fleet. As shown, for most African countries, there is a sharp contrast between the countries' global share of inbound and outbound transport activities taking place in their territory, which is reasonably high, compared to the share of the global mercantile fleet represented by the countries' national fleets, which is low. In other words, African countries generate a significant part of the business, but this business is almost entirely run by third-country operators.

National fleet protection has been cited as a motivation for source taxation of transport profits in a number of countries analysed in this study. In the case of Pakistan, relinquishing source state taxing rights on maritime shipping income over time has been claimed to have stifled the once-thriving domestic maritime and aviation industry. ${ }^{54}$ This consideration is not without problems. Empirical evidence confirming the connection between source taxation and domestic shipping industry development is non-existent. Also, the case of the Philippines shows that if no domestic providers are able to replace services provided by foreign providers who are deterred by source taxation - the Philippines is said to have lost all direct long haul flight connections to Europe by European airlines because of the source tax, without domestic providers being able to offer similar connections - the tax might simply hamper a country's global level of connectivity, and thus increase its cost of transport. If a country does host a national carrier competing for market share, source taxation could be a sensible approach - to counter the impact on this carrier of the liberalisation of the airspace under the so-called 'fifth freedom'. ${ }^{55}$

Regulation and taxation of the international transport business is generally based on two nexus - the flag state/state of registration and the residence state/ownership state. ${ }^{56}$ Environmental standards have for a long time been exclusively enforced under the auspices of the flag state/state of registration. ${ }^{57}$ Recently, certain residence states/ownership states have started to use their domestic shipping tax regimes to incentivise certain environmental standards. A case in point are the recently updated Norwegian, Portuguese and Singaporean tonnage tax systems, which provide rebates for energy efficient and clean ships. Recently, Cyprus has amended its tonnage tax regime to grant as of 2021 a reduction of up to 30 per cent of tax for vessels using biofuels, hydrogen or electric power (NRDC 2018; Lexology 2021). Source taxation could however provide a third nexus to enforce environmental policies, and reinforce the position of the port state as the state that is most affected by climate change (Falcão 2020b).

Climate change is a global phenomenon, yet some of its symptoms - like rising sea levels and extreme weather (precipitation, fog and wind) - particularly affect source state/port states. These states incur extensive infrastructure costs, both in relation to physical damage sustained because of climate change-related events, as well as costs in relation to contingency planning. Cruise shipping is generally seen as a major source of $\mathrm{CO}_{2}$ and other types of pollution. A clear example of this policy conundrum is found in the cruise shipping

\footnotetext{
$54 \quad$ See, for example, Ahmed (2020: 103-119). The author bases his study however on the assumption that a ship's flag state is equal to the residence state for tax treaty purposes. One would believe that a ship's ownership state is what matters for the purpose of a tax treaty, and not necessaritly the flag state. A ship's flag does not entail any income tax consequences.

$55 \quad$ The fifth freedom allows an airline to carry goods and transport between two third countries as a part of services connecting the airline's own country. The fifth freedom is one of the 'freedoms of the air', derived from the Chicago Convention, and which are the fundamental building blocks of the international commercial aviation route network.

56 The flag state of a merchant vessel is the jurisdiction under whose laws the vessel is registered or licensed, and is deemed the nationality of the vessel. Merchant vessel registration is compulsory and can happen in only one jurisdiction, but may be changed over time. The expressions state of registration, flag state and state of nationality are generally considered to be synonymous. 
industry. In a recent policy recommendation by Transport \& Environment, an NGO campaigning for zero emission transport,, the cruise industry was strongly urged to embrace battery technology to generate power when moored in cities. In response, the shipping industry stated that improving the cruise shipping fleet with battery technology is one thing, but this will not solve the problem that few ports have the necessary battery-charging infrastructure, and that provision of this infrastructure requires significant investment by the port states. ${ }^{58}$

Source taxation can aid port states in developing countries to mobilise domestic resources for this purpose, while at the same time incentivising low-impact transport.

The following further considerations determine whether source taxation of international transport is an expedient policy. For each of these issues, consideration should be given to the prime objectives of revenue-gathering, fleet protection and environmental concerns.

\section{- Taxing transport of passengers and/or goods}

It has not been applied in treaty practice, but theoretically it is possible to distinguish between profits from the transport of passengers (no source state taxing rights) and profits from the transport of goods (source state taxing rights). This distinction would effectively result in distinguishing air transport (no source state taxing rights) and maritime transport (source state taxing rights), given the prevalence of the transport of goods over passengers in the maritime shipping industry and the prevalence of transport of passengers over goods in the air transport industry.

\section{- Taxing inbound and/or outbound transport?}

An important policy consideration that was discussed by the UN Committee of Experts during the initial development of Article 8 (Alternative B) of the UN Model is the distinction between inbound and outbound activities. It was generally believed that outbound transport should be taxed at a higher level than inbound transport. It was suggested for the Model provision to distinguish between a lower reduction of source state taxation under domestic tax law on inbound transport than on outbound transport. This nuance is not reflected in the UN Model and Commentary. Given that the Committee was unable to agree on exact rates, the Model merely provides that the rate of source state tax reduction is to be determined in bilateral negotiations.

In practice, this distinction is embraced by a number of countries, but in an inverse way. None of the treaties currently in force provides for such differentiated rates. However, under domestic law in a number of countries analysed, like Indonesia, the Philippines and Sri Lanka, only outbound transport - transport with origin in the source country - is effectively subject to tax, whereas inbound transport is left untaxed.

There is a clear reason for this distinction and for the impetus to avoid taxation of inbound transport. Theoretically speaking, a foreign shipping company that is confronted in the source state with source taxation of shipping income is entitled under the tax treaty to relief from any double taxation to be provided in its state of residence. In practice, levying source taxation might increase the cost of shipping. Shipping companies might face increased compliance burdens due to tax liability in the source state and their tax position in the residence state (tax losses, tonnage tax system, etc.) might make it difficult to obtain a (direct) offset of the tax levied in the source state. This will increase the cost of transport and this cost will be

58 See Transport \& Environment (2019), and reply by the cruise shipping business (Seatrade Cruise News 2019). 
charged to the customer, which in the case of import is located in the source state. The incidence of the source tax lays thus with the economic operators in the source state itself.

A country's 'cost of international transport' is an important key component of economic development, and national policies should be geared to keeping costs as low as possible. A country's cost of international transport is generally considered to be the cost of transport as a fraction of the value of its imports (not its exports). For the reasons mentioned above, source taxation on import transport might adversely affect a country's cost of transport.

From an environmental perspective and the perspective of national fleet protection, there is however no reason to distinguish between inbound and outbound transport.

\subsection{Tax treaty network and negotiation considerations}

The following observations can be made with regard to signing tax treaties to implement a country's desired policy to tax international transport at source.

\section{Are tax treaties necessary?}

A first obvious question is whether tax treaties are necessary to implement a national policy of taxing international transport profits at source. At first sight, tax treaties merely restrict the taxing powers of the signatory states. Without a tax treaty in force, a source state is entitled to tax all profits that are deemed subject to tax under its domestic law. However, the main objective of a tax treaty is not to limit national taxing powers - it is to avoid double taxation. Without a tax treaty having the residence state recognise the taxing rights of the source state, the former is not obliged to provide relief for double taxation in the form of a foreign tax credit or a tax exemption. In the absence of a treaty, such relief for double taxation might be available under the domestic law of the residence state - often it is not, or it is granted at less favourable conditions. Hence, to achieve neutrality of the source tax, it is crucial to sign a tax treaty.

\section{Signing transport tax treaties instead of comprehensive tax treaties?}

Historically, countries sign bilateral transport tax treaties in the absence of or in anticipation of a comprehensive tax treaty. Transport tax treaties are single issue treaties that only deal with double taxation of international transport income. Exclusive residence taxation is often seen as the baseline for negotiations on the matter. Given that these treaties are often simply solidifying domestic law reciprocity clauses (i.e. domestic tax law of a state providing for a tax exemption of non-resident transport income if resident shipping companies are exempt from source tax in the inverse case), transport tax treaties providing for source state taxation of international shipping income are extremely rare.

Even though at the onset of development of the Models, exclusive residence state taxation of shipping income was seen by some as a one-sided concession by the source state, especially in a situation of asymmetrical flows of shipping income, in today's reality the situation is the opposite. Source taxation is perceived as a concession granted by the residence state, which might be required to balance concessions on other issues granted by the source state.

\section{Signing comprehensive tax treaties without Article 8 (international traffic)}

In a number of older treaties signed by some of the Asian countries analysed, the signatory states decided to omit a provision modelled to Article 8 of the OECD Model/UN Model. A 
distinction has to be made between treaties omitting Article 8 with added express exclusion of international shipping profits from the scope of the treaty. Under these treaties, international shipping profits are not affected by the tax treaty, and are dealt with as if no treaty is in force. This implies that the source state can enforce its domestic tax law without restriction, yet the residence state is in no way obliged to grant relief for double taxation.

A number of treaties omitting Article 8 do not contain an express exclusion of shipping profits from the scope of the treaty. Under these treaties, shipping profits fall under the standard rule on business profits laid down in Article 7 of the Models. This implies that the source state can tax international shipping profits to the extent that the PE threshold is met. Given the prevalence of exclusive residence state taxation, there is little international practice indicating whether and to what extent transport activities in the source state give rise to a PE. It is clear, however, that the PE threshold is different than the activity threshold (more than casual) in Article 8 (Alternative B) of the UN Model. The UN Model Commentary provides that shipping activities are more than casual if it concerns a scheduled or planned visit of a vessel. Whether a visit - planned or unplanned - gives rise to a PE depends however on the existence of a place of business in the source state that is fixed, and through which the business is carried on.

In treaty practice of the countries analysed, no activity threshold has been adopted in relation to source state taxing rights granted under Article 8. It is clear that applying Article 7 to international transport activities grants less extensive source state taxing rights, but nevertheless allows source state taxation in certain circumstances. This might be a valid policy option.

\section{Choice of tax treaty partner}

To the extent that the focus is on taxing profits from the maritime shipping of goods - it should be taken into account that over all individual segments of the industry, ownership of the business is centralised in the hands of enterprises located in only a handful of countries. Implementing a source tax policy should focus on signing or amending tax treaties with those countries. Which countries depends on the size and segments active in the individual country. If a country has a sizeable activity exporting oil and other hydrocarbon products, it can be assumed that the vessels involved are to a large extent owned by shipowners located in Greece or Japan. Obviously this is an approximation that needs to be verified based on actual port call data.

It is important to scrutinise carefully which countries are selected to implement the policy, and to steer clear of making tax treaty concessions to insert source state taxation of shipping profits if these treaties are being signed with states that do not host a sizeable shipping industry that generates transport activities in the country. If this is not the case, the cost of treaty concessions to obtain source taxation might exceed the benefits of source taxation.

Additional focus should be on neighbouring countries and countries in near proximity with sizeable domestic fleets. A prime example is the Indonesia Singapore Tax Treaty, which provides for source taxation and is crucial for Indonesia to tax the massive influx of Singaporean operators providing domestic transport in Indonesia. In Indonesia, the levying of source taxation under the Treaty is seen as extremely relevant to protect its domestic fleet.

\section{Geographic location of the country in question}

Finally, research on the global practice in tax treaties of adopting source state taxation of international shipping profits, shows that the practice is currently concentrated in a single 
region, namely South/South-East Asia. Two elements explain the concentrated regional character of this particular tax treaty practice. First, all the countries that have embraced source taxation are blessed with a geographical position on one of the major maritime line shipping routes - namely the Europe-Asia Pacific route. As such, these countries do not have to rely on their domestic policies to actively attract shipping lines. Second, there are clear benefits in adopting source taxation as a regional cluster of countries as it creates a regional level playing field and avoids individual countries adopting a beggar my neighbour policy. If international shipping companies are confronted with source taxation in the whole region, it is less likely that these companies will reroute traffic for the purpose of avoiding source taxation.

Whereas most African countries - especially sub-Saharan countries - do not benefit from a similar beneficial position in the global shipping network, the countries should strive for a regional approach towards the implementation of source taxation of shipping income. For instance, coastal countries like Ivory Coast, Ghana, Togo, Benin and Nigeria have all expressed interest in adopting source taxation. To implement this policy effectively and to avoid tax-induced distortions of the business, the countries should deal with this issue as a cluster of countries, and coordinate their approach towards amending or signing tax treaties with individual ship-owning states. This coordination could entail joint and/or parallel tax treaty negotiations (Falcão and Michel 2020a).

\section{Arguments countering a principled stance to conserve exclusive residence state taxation}

Source taxation is not part of the residence state's tax treaty policy. Research shows that each of the ten biggest ship-owning nations has in at least one tax treaty agreed to grant source state taxing rights in relation to maritime shipping income. Similarly, nearly all OECD member states have agreed to source taxation in one or more of their tax treaties.

There is a historic consensus on exclusive residence state taxation. There is a longstanding praxis in tax treaties to tax shipping profits exclusively in the residence state. From the onset of the development of the first models, opinions regarding the theoretical underpinnings of exclusive residence state taxation have been divided. Theories on the division of taxing rights, like benefits theory, the theory of economic allegiance, and theories of distributive justice, do not exclude source taxation. Exclusive residence state taxation has prevailed in practice only because of practical considerations regarding enforceability and compliance.

Enforceability and compliance difficulties make source state taxation impossible. This 1920 s creed has lost much of its merit in the age of data and transparency in tax matters. If in the era of digital economy, offshore providers of digital services can be forced to collect data on their virtual business in a certain country, shipping companies should be deemed able to collect and compile data on their shipping activities per destination. In many instances this data exists, if not for the companies own managerial purposes, then for the purpose of complying with other regulatory requirements - such as port duties and excise taxes (Falcão and Michel 2020b).

There is no guidance available regarding profit attribution. This is correct with regard to the UN Model, and this lacuna needs to be addressed. If the UN Model provides for source state taxing rights on shipping profits, it should also provide for detailed guidance on profit attribution under this taxing right, just as the models do vis-à-vis the attribution of profits to PEs. 
Profit attribution guidance and practice does exist, however. The bilateral tax treaty network is far from complete, and any of the major shipowner states, has been confronted in the past with its resident companies deriving shipping profits from source countries with which no tax treaty is enforced. Hence, even countries staunchly defending exclusive residence state taxation have an interest in developing generally accepted standards for profit attribution for shipping companies. This explains, for instance, why IATA strongly advocates for exclusive residence state taxation, yet at the same time encourages its member countries to embrace the standardised profit attribution rules.

Also, in the inverse case, it makes sense for residence countries to develop profit attribution rules. The example of Australia illustrates that residence countries generally do have experience with the attribution of locally sourced shipping profits derived by non-resident shipping companies located in countries without a treaty. Countries like Australia tax these profits under their domestic law, even if levying tax at source on shipping profits is clearly contrary to their tax treaty policy. This is explained by the fact that residence countries will usually use this tax as a bargaining chip and exercise their tax sovereignty under domestic law merely to encourage other states to sign tax treaties and to obtain concessions in exchange for limiting the exercise of this sovereignty. The exercise of this sovereignty required profit attribution rules, and hence Australia's adherence to the methods proposed by IATA.

\section{The international shipping business operates at tight profit margins and is very} capital-intensive - source taxation might stifle the profit margins. Most analysists agree that the pressure on profit margins in the biggest shipping enterprises is generated by the creation of over-capacity. One of the reasons used to explain the recurring problem of overcapacity is said to be the untargeted use of preferential tax regimes for shipping companies in shipowner states, like tonnage tax systems. These regimes artificially stimulate the creation of over-capacity that puts pressure on the profit margins. It would be perverse to fend off source taxation for a problem that is partly caused by inefficient tax policies in the residence state. On the contrary, source taxation could serve as a minimum tax, thereby alleviating the creation of overcapacity.

\subsection{Considerations regarding drafting of the treaty provision}

With regard to tax technical considerations for drafting the treaty provision, it is advisable to revert to the building blocks identified in the analysis of tax treaty practice. These building blocks are: income covered, source state taxing rights, sourcing rule, method of taxation, and interaction with domestic law.

\section{Income covered}

Under the Models, the international transport article covers income from the operation of ships in international traffic, with international traffic covering both cross-border transport as well as domestic transport provided by a foreign enterprise (cabotage). Certain treaties restrict source state taxing rights only to cover income from cabotage.

Under Article 8 (Alternative B) of the UN Model, source state taxing rights are granted only to income from international maritime shipping, not air transport. This is usually followed in treaty practice, although it is a valid policy option to also grant source state taxing rights to air transport profits.

The activity threshold (more than casual) in Article 8B of the UN Model has not been adopted in treaty practice, arguably because of interpretational difficulties. De minimis rules for liability 
are better inserted into domestic law of the source state, for the latter to keep control over the scope and impact of the exemption threshold.

Under the OECD Model - which has an inherent bias to favouring residence states - there is a policy pull towards expanding the scope of business income covered under the international transport article, because all income covered under Article 8 avoids possible source state taxation by application of the PE rule of Article 7. As such, not only profits directly obtained from transport activities, but also profits from activities directly connected with these operations, and profits not directly connected but ancillary to transport operations are included. ${ }^{59}$ Examples of these profits covered are profits from wet leasing of ships or aircraft, profits from connected transport on different transport modes by land, profits from ticket sales on behalf of other transport companies for transport connected to its own transport activities, and profits from the lease of containers for the transport of goods or temporary storage of goods. This understanding of the extensive scope of Article 8 is also absorbed in the UN Model.

To the extent source state taxing rights are granted in the tax treaty, these rights apply to all income deemed covered under Article 8. The fact that under Article 8B source state rights are granted that are not granted under Article $8 \mathrm{~A}$ of the UN Model does not alter the scope of the income covered under the Article, which is the extensive scope reflected in the OECD Commentary. States do not need to make this explicit in their tax treaties.

\section{Source state taxing rights}

There is a consensus amongst states adopting source taxation and the drafters of the UN Model that the taxing rights granted cannot be exercised without limitations, and that a source state should at least agree to grant a reduction of the tax normally levied on nonresident shipping income under its domestic tax law.

Two policy options exist - a proportional reduction, or an absolute maximum threshold as in the case of source taxation on passive income. The UN Model and most treaty practice applies a proportional reduction, which is usually set at 50 per cent but which ranges across treaties between 40 and 66 per cent. The Philippines is the only country that favours the inclusion of an absolute threshold, formulated as a maximum percentage of tax on gross income covered. In the case of the Philippines, the limit is set at a maximum of 1.5 per cent of tax.

Jurisprudence in Indonesia shows that there is a strong argument in favour of using a proportional threshold rather than an absolute threshold. The absolute threshold implies that the rate - usually determined as a fixed reduction of the standard gross rate on shipping income under domestic law (e.g. 2.5\%) - implies that this is the maximum rate applicable to all income covered under the shipping article in the tax treaty. As shown above, the scope of the income covered under the shipping article is usually wide, as it covers also directly connected and ancillary income. However, income covered under the shipping article in the treaty is not necessarily income considered as shipping income under domestic law. For instance, domestic tax law might provide a low rate of 2.5 per cent on ordinary shipping income, but ancillary income from ticket sales might be taxed at the ordinary rate (e.g. $20 \%$ ) on services provided by non-resident service providers. A reduction of this rate to the absolute maximum rate of 1.5 per cent in the treaty might not be desirable, whereas a proportional reduction of the 20 per cent rate by 50 per cent might be more suitable.

59 See OECD Model (2017), Commentary on Article 8, para 4 et seq., Treaties and Models, IBFD. 
Finally, in treaties that expressly provided source state taxing rights for profits from cabotage (but not for other types of international transport), the source state taxing rights are usually granted without limitation.

\section{Sourcing rule}

The sourcing rule determines which income is deemed to be derived from sources in the source country, and which income can thus be taxed in the country.

In the treaty practice of the countries studied, there is a wide variety of wording used. There are three types of sourcing rules used in treaty practice: the no-rule source rule, the open end source rule, and the limited source rule. The limited source rule is the standard rule used in most treaties, and also in Article 8B of the UN Model. It limits the scope of source state taxing rights to income from transport taking place in the source state. The nexus is the place where the operation of the transport takes place. If part of it takes place in the source state, the source state can tax the profits attributable to this part of the activities. The open rule refers to income derived from the source state, without any further specification. Income can be deemed to be derived from the source state because part of the transport takes place in the source state, but also because payments for the transport have been made in the source state, regardless of whether the transport takes place in the source state or not. In this case, the nexus is to be defined under domestic law of the source state. A similar outcome is achieved under the 'no-rule rule'. A surprisingly high number of treaties omit any definition of source in the treaty provision. These treaties merely provide that the source state can tax income from international traffic, without further specification. Albeit probably a design flaw rather than intentional policy, this rule implies that the source state can tax international transport profits even if there is no nexus or little nexus at all with the source state.

It is believed that the most optimal solution is the limited source rule, given that it focuses on the place of activities, rather than the place of the payer. Article 8B should be seen as a variation to the PE rule - which also used the place of activities as the nexus, rather than a variation on Article 12A of the UN Model on 'fees for technical services'. Under Article 12A, fees for technical services are deemed to arise in a state if the payer is a resident of that state. ${ }^{60}$ Source taxation of shipping profits should not follow this approach. The purpose is to tax international transport activities that take place in the source state. The focus should not be on taxing base-eroding payments in the source state for transport services rendered elsewhere.

Under domestic tax law of certain countries, like the Philippines and Sri Lanka, the limited source rule is further restricted by providing that only payments, wherever made, for outbound transport are deemed to have their source in the country. Given what has been mentioned above regarding inbound and outbound transport, this rule should be considered best practice, and - albeit never tested in actual treaty practice - nothing prevents a state from inserting this restriction in the tax treaty itself. Countries like Pakistan and India employ a mixed nexus approach in their domestic law to tax gross payments, wherever received, for outbound transport, and gross payments for inbound transport if received in Pakistan. In this case, payments abroad for inbound transport are left untaxed.

The research also revealed that other countries have the understanding that source state taxing rights can de facto only be exercised if the payer of the transport services is located in the source country where the transport takes place. Therefore, 8B-type treaty provisions 
would not apply in those triangular cases where the payer of the transport services is situated in a third country (a country other than that where the goods are to be delivered). A typical example would an American MNE signing a contract with a European transport company to pick up consumer goods that have been manufactured by an Indonesian subcontractor, and are to be transported to the logistical distribution centre of the MNE in Europe. In this case, since there is no corresponding payment in Indonesia for the transport, no tax can be withheld on gross receipts. To circumvent this problem, domestic law in the source state should instate a requirement for non-resident transport companies to register in the country and to assign a trading agent. The trading agent would then be responsible to collect the tax due based on the information received by its principal.

\section{Method of taxation and interaction with domestic law}

Unless the treaty provision provides for an absolute threshold of a maximum tax rate levied on gross receipts, the treaty provision is drafted in neutral terms regarding the choice for the source state to tax non-resident shipping income on gross or on net basis.

In practice, most countries analysed tax gross income at a rate that is significantly lower than the statutory corporate tax rate. The tax is levied on gross receipts for inbound and outbound transport. The statutory rate of tax on gross non-resident shipping income is often based on a deemed profit margin, taxed at the statutory corporate tax rate. Sri Lanka appears to be the only exception, allowing net taxation at the ordinary corporate tax rate, but only if the nonresident meets the domestic PE threshold.

Arguably, a suitable approach might be to offer non-resident taxpayers the choice between gross taxation based on effective receipts and a deemed profit margin taxed at the ordinary tax rate, irrespective of losses or expenses, and net taxation with application of the maritime formula or Calcutta formula to take into account losses and expenses. To some extent, this dual system would mirror the policies employed in the shipowner state that often consist of granting an optional tonnage tax system, which is essentially a system allowing taxation based on fleet capacity (instead of receipts), and a deemed profit margin taxed at the ordinary tax rate - also without taking into account losses and expenses. 


\section{References}

African Tax Administration Forum (2019), ATAF Model Tax Agreement for the elimination of double taxation with respect to taxes on income and the prevention of tax avoidance and evasion, available at:

https://events.ataftax.org/events/index.php?page=documents\&func=view\&document_id $=7$

Ahmed, M. (2020) 'UN MTC Article 8: Was the Source Rule Surrender on Article 8 a Blunder? The Case Study of Pakistan', Intertax 48(1): 113

Amurao, B. (2012) 'International Carriers Taxation in the Philippines', NTRC Tax Research Journal Vol. XXIV.2: 7

CEPR VOXeu (2020) 'International corporate taxation after COVID-19: Minimum taxation as the new normal', 14 April 2020, available at: https://voxeu.org/article/minimumeffective-tax-rate-global-multinational-profits (last accessed: 15 February 2021)

The Economist (2020) 'How covid-19 put wind in shipping companies' sails', 10 October 2020, The Economist, available at: www.economist.com (last accessed: 1 January 2021)

European Commission (2019) 'State aid: Commission approves maritime transport support schemes in Cyprus, Denmark, Estonia, Poland and Sweden', Press release, 19 December 2019, available at:

https://ec.europa.eu/commission/presscorner/detail/en/IP_19_6780 (last accessed: 1 February 2021)

- (2016) Proposal for a Council Directive on a Common Consolidated Corporate Tax Base (CCCTB), 25 October 2016, COM(2016) 683 final

Falcão, T. (2020a) 'Can the Digital Economy Debate Improve the Taxation of International Shipping Profits?', Tax Notes International, 24 August 2020

_ (2020b) 'Taxing Emissions on the High Seas', Tax Notes International, 31 August 2020

_ (2019) 'Taxing Carbon Emissions from International Shipping', Intertax Law Journal $47(10)$

and Michel, B. (2020a) 'Comments on the draft Toolkit on Tax Treaty Negotiations', Open Consultation Procedure, Platform for Collaboration on Tax (PCT), Toolkit on Tax Treaty Negotiation, October 2020

(2020b) Tax Consequences of the Digitalized Economy, Input to the United Nations Committee of Experts on International Cooperation in Tax Matters, June 2020, available at:

https://www.un.org/development/desa/financing/sites/www.un.org.development.desa.fi nancing/files/2020-

06/Article\%2012A_digital\%20services\%20UNTC\%20submission\%20final.pdf 
Hearson, M. (2021) Tax Treaties Explorer [Online database], Brighton: International Centre for Tax and Development (ICTD), retrieved from https://www.treaties.tax (last accessed: 15 March 2021)

IATA (2018) 'Comments on revision of national aviation policy in Pakistan', 14 December 2018, available at: http://docs. publicnow.com/viewDoc.asp?filename=41118\%5CEXT\%5C88EA47DC5E7 530ADB0289E4BCC2AC37D106FAE12_28E14CF4E29989942CC37C8F8B4BCFBE8 ABA5754.PDF (last accessed: 1 January 2021)

- (2013) OECD Memorandum on Transfer Pricing Documentation and Country By Country Reporting, 6 November 2013, available at:

https://www.iata.org/contentassets/a72d8d3cfaf84529bcdef6b2dc59f224/cbc_reporting. pdf (last accessed: 1 January 2021)

IBFD (2021) Tax Treaty Database, available at: https://research.ibfd.org/\#/

Ministry of Transport, Indian Shipping Statistics 2013, at Government of India Ministry of Transport, available at: http://shipmin.gov.in/sites/default/files/ISS\%202013.pdf (last accessed: 15 March 2021).

ITF (2019) Maritime Subsidies - Do They Provide Value for Money?, International Transport Forum Policy Papers No. 70, available at: https://www.itfoecd.org/sites/default/files/docs/maritime-subsidies-value-for-money.pdf (last accessed: 15 February 2019)

League of Nations (1925) Double Taxation and Tax Evasion. Report and Resolutions, submitted by the Technical Experts to the Financial Committee of the League of Nations (doc. F 212) (7 Feb. 1925)

(1923) Report on Double Taxation Submitted to the Financial Committee by Professors Bruins, Einaudi, Seligman and Sir Josiah Stamp, (doc. E.F.S. 73 and F19) (5 Apr. 1923)

Lexology (2021), 'Greener waters - Cyprus announces 30\% tax reduction for energy efficient vessels', Lexology, 26 January 2021, available at:

https://www.lexology.com/library/detail.aspx?g=76263378-c75a-459d-ac32-

f517c3bbe0c3 (last accessed: 15 February 2021).

Maisto, G. (2003) 'The History of Article 8 of the OECD Model Treaty on Taxation of Shipping and Air Transport', Intertax 31(6/7)

Merk, O. (2020) 'Quantifying tax subsidies to shipping', Maritime Economics \& Logistics 22: 517-535

Michel, B. (2019) 'The French Crusade to Tax the Online Advertisement Business: Reflections on the French Google Case and the Newly Introduced Digital Services Tax', Eur. Taxn. 59(11), Journal Articles \& Opinion Pieces IBFD (accessed 10 Mar. 2021)

NRDC (2018) Incentive Schemes for Promoting Green Shipping, available at: https://www.nrdc.org/sites/default/files/incentive-schemes-promoting-green-shippingip.pdf (last accessed: 15 February 2021) 
OECD (2020a) Tax Challenges Arising from Digitalisation - Report on Pillar One Blueprint: Inclusive Framework on BEPS, OECD/G20 Base Erosion and Profit Shifting Project, Paris: OECD Publishing, https://doi.org/10.1787/beba0634-en (last accessed: 1 January 2021)

- (2020b) Inclusive Framework on BEPS: Action 5, Harmful Tax Practices - Peer Review Results, Update (as of November 2020), available at:

https://www.oecd.org/tax/beps/harmful-tax-practices-peer-review-results-onpreferential-regimes.pdf (last accessed: 1 February 2021)

- (2015a), Countering Harmful Tax Practices More Effectively, Taking into Account Transparency and Substance - Action 5: 2015 Final Report, OECD/G20 Base Erosion and Profit Shifting Project, available at: http://dx.doi.org/10.1787/9789264241190-en (last accessed: 1 February 2021

(2015b) Preventing the Granting of Treaty Benefits in Inappropriate Circumstances Action 6: 2015 Final Report, OECD/G20 Base Erosion and Profit Shifting Project

(2015c) Transfer Pricing Documentation and Country-by-Country Reporting, Action 13 2015 Final Report, OECD/G20 Base Erosion and Profit Shifting Project, Paris: OECD Publishing, http://dx.doi.org/10.1787/9789264241480-en (last accessed: 1 January 2021)

(2013) Proposed changes to the OECD Model Tax Convention dealing with the operation of ships and aircraft in international traffic, available at:

https://www.oecd.org/ctp/treaties/Discussion-draft-international-taffic.pdf (last accessed: 1 January 2021)

Seatrade Cruise News (2019) Report makes unfounded cruise pollution claims, say cruise line and port associations, 6 June 2019, available at: https://www.seatradecruise.com/news-headlines/report-makes-unfounded-cruise-pollution-claims-saycruise-line-and-port-associations (last accessed: 15 February 2021).

Transport \& Environment (2019), Luxury cruise giant emits 10 times more air pollution (SOx) than all of Europe's cars - study, 4 June 2019, available at:

https://www.transportenvironment.org/discover/luxury-cruise-giant-emits-10-timesmore-air-pollution-sox-all-europes-cars-study/(last accessed: 15 February 2021)

UNCTAD (2019) United Nations Conference on Trade and Development - Review of Maritime Transport 2019, available at:

https://unctad.org/en/PublicationsLibrary/rmt2019_en.pdf (last accessed: 15 February 2021)

United Nations (2017) United Nations Model Double Taxation Convention between Developed and Developing Countries, Treaties and Models, IBFD.

(1972) Tax Treaties Between Developed And Developing Countries - Third Report, [ST.ECA.166][E.72.XVI.4] 
_ (1969) Tax Treaties Between Developed And Developing Countries - First Report, [E.4614 ST.ECA.110][E.69.XVI.2]

Wijnen, W. and De Goede, J. (2014) 'The UN Model in Practice 1997-2013', Bulletin for International Taxation, March 2014, pp. 118-147

— and Magenta, M. (1997) 'The UN Model in Practice', Bulletin for International Taxation, December 1997, pp. 574-585 